\title{
Umiejętność poszukiwania hiperonimów o wysokim poziomie ogólności przez osoby niewidome i widzące
}

The ability of searching for hypernyms with a high degree of generality

by persons with impaired sight and the blind ${ }^{1}$

\author{
Nawoja Mikołajczak-Matyja \\ Instytut Językoznawstwa, Uniwersytet im. Adama Mickiewicza \\ ul. Międzychodzka 5, 60-371 Poznań, POLSKA \\ nawomiko@amu.edu.pl
}

\begin{abstract}
The ability of searching for hypernyms with a high degree of generality by persons with impaired eyesight and the blind is thoroughly described. The present paper concerns the hierarchically organised structure of the mental lexicon. The final elements of hierarchical series of hypernyms constructed for 75 Polish nouns by 116 subjects ( 58 blind people and 58 sighted people) were analysed and compared.
\end{abstract}

\section{Poszukiwanie elementów nadrzędnych struktury hierarchicznej słownictwa jako problem językoznawczy i psycholingwistyczny}

Zadaniem psycholingwistyki jest zarówno odkrywanie mechanizmów językowego funkcjonowania człowieka, jak i stwierdzanie stopnia realności psychologicznej wyników analiz językoznawczych. Przedmiotem zainteresowania obecnej pracy jest sposób odzwierciedlenia górnych części hierarchii leksykalnej warstwy języka w strukturze leksykonu umysłowego oraz zależność tego odzwierciedlenia od rodzaju doświadczeń użytkownika języka.

Jednym z głównych aspektów paradygmatycznej struktury słownictwa języka naturalnego jest jego budowa hierarchiczna. Podstawowe pytania zadawane przez semantyków w odniesieniu do tej struktury dotyczą: obszarów słownictwa podlegających hierarchizacji, istnienia elementów nadrzędnych w hierarchiach, rodzajów i regularności hierarchii.

Trudność objęcia jedną hierarchią nie tylko całego słownictwa danego języka, ale także zbioru wszystkich leksemów należących do danej kategorii gramatycznej czy nawet jego głównych podzbiorów (takich, jak np. rzeczowniki abstrakcyjne czy czasowniki przechodnie), prowadzi do poszukiwania oddzielnych hierarchii dla poszczególnych pól leksykalno-semantycznych, stanowiących odzwierciedlenie pojęciowej wiedzy o rzeczywistości [Lyons 1984, Saeed 1998, Allan 2001]. Główny problem z uporządkowaniem hierarchicznym dużych obszarów słownictwa polega na znalezieniu elementu nadrzędnego, tj. połączonego relacją inkluzji $\mathrm{w}$ stosunku do wszystkich innych elementów hierarchii.

Podstawową relacją porządkującą słownictwo na zasadach hierarchicznych jest relacja zawierania klas, czyli hiponimii, umożliwiająca m.in. tworzenie struktur określanych jako taksonomie [Cruse 1986, 2000; Allan 2001]. Jako przykłady rzeczowników mogących zajmować dość wysokie miejsca $w$ hierarchiach opartych na zasadach hiponimii Lyons [1984] podaje

\footnotetext{
${ }^{1}$ Summary in English is available at the end of the main text (ed. note).
} 
następujące leksemy: entity (może on stanowić, zdaniem Lyonsa, hiperonim zbioru wszystkich rzeczowników policzalnych) oraz object, thing, person, animal, fish, bird, insect, place, stuff, material, quality, property i state, stanowiące hiperonimy podzbiorów rzeczowników „drugiego rzędu". W taksonomiach szczególną rolę odgrywa tzw. poziom podstawowy, zawierający takie leksemy, jak: samochód, kot czy jabłko, a więc ,zwykłe, codzienne nazwy obiektów” [Cruse 1986:146]. Uważa się, że odpowiadające tym nazwom pojęcia wyodrębniają się najwyraźniej w świadomości użytkowników, ponieważ stanowią maksymalny kompromis między informacyjnością a dystynktywnością (tzn. przypisanie obiektu do kategorii z tego poziomu pozwala wnioskować o stosunkowo wielu jego nieobserwowalnych cechach, a jednocześnie stosunkowo łatwo jest odróżnić ten obiekt od innych z tego poziomu, por. [Bloom 2000]). Jednakże wiele odgałęzień hierarchii kończy się na tym poziomie, a dla niektórych hierarchii, zwłaszcza abstrakcyjnych, trudno jest go zdefiniować [Cruse 1986; Miller 1993].

Drugą ważną relacją stanowiącą podstawę hierarchicznego uporządkowania słownictwa jest meronimia, czyli szeroko rozumiana relacja czesść - całość. Ograniczenia w przechodniości meronimii zmniejszają ciagłość hierarchii wyznaczanych przez tę relację i uniemożliwiają obejmowanie jedną hierarchią wszystkich istniejących obiektów [Cruse 1986]. Ograniczenia w przechodniości postrzegane są m.in. jako rezultat istnienia różnych rodzajów relacji część - całość, takich, jak: składnik - obiekt, element - zbiór, porcja - masa, materiał - obiekt, cecha (element) działania (zdarzenia) - działanie (zdarzenie), miejsce - obszar oraz faza - proces [Miller 1993; Saeed 1998; Allan 2001]. Jeszcze bardziej szczegółowy podział relacji określonych jako element zbiór i materiał - obiekt można znaleźć u Cruse'a [1986]. Wysokie poziomy hierarchii wyznaczonych przez meronimię to nazwy dużych całości. Cruse [1986] podaje przykłady hipotetycznych leksemów tego typu: universe, terrestrial biomass, population.

Jedną z różnic między dwoma wymienionymi rodzajami hierarchii jest poziom występowania luk leksykalnych: w taksonomiach niekiedy brakuje terminu nadrzędnego hierarchii obejmującej nawet niezbyt duży wycinek słownictwa (por. np. w języku polskim i angielskim brak bezpośredniego hiperonimu przymiotników oznaczających nazwy kolorów, funkcjonuje jedynie rzeczownikowy quasi-hiperonim kolor czy barwa, ang. colour), podczas gdy podział na części jest ściśle związany z istnieniem nazwy całości, natomiast często nie ma oddzielnej nazwy dla głównej funkcjonalnej części obiektu takiego, jak np. łyżka (Cruse 1986, 2000; por. także Lyons 1984).

Hierarchiczna struktura słownictwa odzwierciedlona jest w definicjach leksykograficznych, zgodnie $\mathrm{z}$ realizacją jednej $\mathrm{z}$ podstawowych reguł definiowania, mówiącej o konieczności wyjaśniania definiendum przez jednostki semantycznie prostsze (por. np. Apresjan 1972; Grochowski 1985, Péchoin 1989, Mikołajczak-Matyja 1999). Regularność i ciągłość hierarchii definicyjnych wiąże się z problemem tzw. indefinibiliów semantycznych. Wg niektórych autorów do roli takich indefinibiliów mogą pretendować jednostki leksykalne o bardzo szerokich zakresach, a więc zajmujące wysokie miejsca w hierarchiach typu hiponimicznego (por. Grzegorczykowa 1988, Hammerl i Sambor 1993).

Relacje wyznaczające hierarchizację słownictwa są także ważnym elementem budowy nowoczesnej formy słowników, jaką stanowią bazy leksykalne (por. np. Miller, Beckwith, Fallbaum, Gross, Miller 1993, Miller 1993, Fellbaum 1993, Dolan, Vanderwende, Richardson 2002). To właśnie hierarchizacja jest główną zasadą porządkującą rzeczownikową część bazy WordNet, skonstruowanej przez Millera i jego współpracowników. Wątpliwości co do wyboru właściwego leksemu obejmującego swoim zakresem wszystkie rzeczowniki spowodowały uporządkowanie tej części słownictwa angielskiego w 25 oddzielnych (chociaż nie całkowicie rozłącznych) hierarchiach. Jako elementów nadrzędnych tych hierarchii użyto następujących leksemów lub ich zbiorów:

$\begin{array}{llll}\text { act, action, activity } & \text { event, happening } & \text { natural phenomenon } & \text { shape } \\ \text { animal, fauna } & \text { feeling, emotion } & \text { person, human being } & \text { state, condition } \\ \text { artifact } & \text { food } & \text { plant, flora } & \text { substance } \\ \text { attribute, property } & \text { group, collection } & \text { possession } & \text { time } \\ \text { body, corpus } & \text { location, place } & \text { process } & \\ \text { cognition, knowledge } & \text { motive } & \text { quantity, amount } & \end{array}$


(Miller 1993:16). Elementy nadrzędne 25 hierarchii bazy WordNet, wyodrębnione dla celów praktycznych, można uważać za zróżnicowane pod względem ogólności, i za oddalone (w różnym stopniu) od wyrażeń o potencjalnie najszerszych zakresach znaczeniowych. Podane przez Millera przykłady leksemów o wyższym poziomie ogólności (organism, living thing, non-living thing, object, thing, idea oraz entity), mogące łączyć kilka wymienionych hierarchii, pokrywają się częściowo z ogólnymi leksemami wyszczególnionymi przez Lyonsa. Omawiana baza uwzględnia także niektóre rodzaje meronimii (składnik - obiekt, element - zbiór i materiał - obiekt), głównie w odniesieniu do rzeczowników desygnujących ilość, artefakty i ciało ${ }^{2}$.

Baza WordNet ma z założenia odzwierciedlać zasady budowy leksykonu umysłowego użytkownika języka [Miller 1993]. Hierarchizacja stanowi przejaw uporządkowania semantycznego leksykonu umysłowego jako jednej z głównych zasad jego organizacji (Reeves, Hirsh-Pasek, Golinkoff 1998, por. także np. Forster 1976, McClelland \& Rumelhart 1981, Levelt, Roelofs, Meyer 2002]. Założenie o hierarchicznej strukturze leksykonu umysłowego i pamięci semantycznej wspierane jest wieloma dowodami pochodzącymi $\mathrm{z}$ różnych badań psycholingwistycznych: z badań skojarzeniowych (por. Woodworth i Schlosberg 1963, Deese 1965, Kurcz 1967, Łobacz i Mikołajczak-Matyja 2002), badań nad podejmowaniem decyzji leksykalnych (np. Collins, Quillian 1969) i nad definicjami (np. McGhee-Bidlack 1991, Mikołajczak-Matyja 1998) oraz z badań dotyczących posługiwania się rzeczownikami anaforycznymi i konstrukcjami porównawczymi (Miller 1993).

Metodą pozwalającą na zbadanie górnych poziomów hierarchii leksykonu umysłowego jest uzyskiwanie tzw. psychologicznych ciagów definicyjnych. Badania nad ciągami definicyjnymi, zapoczątkowane w latach 70-tych przez Martina (1974), prowadzone były początkowo na materiale leksykograficznym (Martin 1974, Artowicz 1990, Hammerl, Sambor 1993). W wyniku analizy 1000 ciągów zrekonstruowanych na podstawie definicji rzeczowników z Małego Słownika Języka Polskiego znaleziono następujące wyrazy o wysokim stopniu ogólności: ktoś, coś, to, substancja, materia, istota żywa, organizm, stworzenie, twór, przedmiot, rzecz, miejsce, czesść, układ, zespót, zbiór, grupa, ogót, suma, system, catość, cecha, czynność, system, sposób, proces (Hammerl, Sambor 1993). Możliwość wielostronnej analizy ciagów definicyjnych skłoniła badaczy do prowadzenia badań nad tzw. ciagami psychologicznymi, otrzymywanymi od respondentów w badaniach ankietowych. Zadaniem respondentów w takich badaniach jest budowanie (począwszy od podanych haseł) szeregów wyrazów, z których każdy następny jest hiperonimem w stosunku do poprzedniego. Zatem końcowe elementy ciagów prawidłowych wskazują, wyrazy o jakim maksymalnym stopniu ogólności można uznać za elementy spójnych hierarchii w leksykonie umysłowym. W badaniach tego typu przeprowadzonych w Polsce na materiale 100 rzeczowników desygnujących rośliny, jako hiperonimy końcowe ${ }^{3}$ wystąiły leksemy o zróżnicowanym stopniu ogólności, od takich jak owoc czy roślina (najczęstszy hiperonim końcowy), aż po tak ogólne, jak: organizm, istota, rzecz, materia, życie, struktura, część, coś, zbiór (Sambor, Zagrodzka 1993). Na szczególną uwage zasługuje dość wysoka liczba wystapień hiperonimu końcowego rzecz, interpretowana przez autorki jako wynik konceptualizowania niektórych roślin (zwłaszcza owoców jadalnych) jako przedmiotów martwych. Rodzi się jednak pytanie o możliwość przypisywania temu leksemowi przez respondentów znaczenia szerszego, zbliżającego go do rzeczownika byt. Dowodem tego może być także stosowanie określenia rzecz żywa (podanego w innej pracy

\footnotetext{
${ }^{2} \mathrm{~W}$ pewnym stopniu zhierarchizowana jest również czasownikowa część bazy. Wewnątrz 15 głównych pól semantycznych uwzględniono m.in. taksonomie oparte na relacji sposobu (,troponimii”), którą można traktować jako odmianę hiponimii dostosowaną do właściwości semantycznych czasowników. Hierarchie czasowników są płytsze i bardziej rozgałęzione, niż rzeczownikowe (Fellbaum 1993).

3 „Góra“ hierarchii kojarzy się raczej z jej początkiem, a nie końcem, jednakże w przypadku ciagó́w reprezentujących rekonstrukcję struktury hierarchicznej od szczegółu do ogółu (od dołu do góry) element najbardziej ogólny umieszczony jest na końcu budowanego ciagu (jest to element końcowy ciagu), stąd użycie terminu „hiperonim końcowy“ (por. np. Sambor, Zagrodzka 1993).
} 
referującej wyniki tych badań, por. Szczekocka-Augustyn, Wereszczyńska, Zagrodzka 1996). Stosowanie leksemu rzecz jako elementu końcowego ciagu (w znaczeniu szerszym bądź węższym) mogło być także zainspirowane przykładami zawartymi $w$ instrukcji do badania ${ }^{4}$. W opisie analogicznych badań przeprowadzonych na materiale 100 nazw artefaktów autorki rejestrują pojawianie się (na różnych miejscach ciagu) takich dość ogólnych leksemów, jak urzqdzenie i przedmiot (Szczekocka-Augustyn, Wereszczyńska, Zagrodzka 1996).

Rozszerzenie takich eksperymentów na wyrazy pochodzące z wielu pól semantycznych pozwoli na ustalenie ogólniejszych zasad budowania górnych części hierarchicznych uporządkowań wewnątrz słownika umysłowego. Natomiast analiza ciagów uzyskanych od grup respondentów o wyraźnie zróżnicowanych doświadczeniach umożliwi określenie wpływu takich doświadczeń na strukturę leksykonu. Źródłem silnej odmienności doświadczeń są m.in. zaburzenia funkcjonowania narządów zmysłów. Porównanie psychologicznych ciągów definicyjnych uzyskanych od osób z defektem określonego narządu zmysłu z ciągami budowanymi przez osoby bez takiego defektu może wskazać wpływ informacji uwarunkowanych działaniem uszkodzonego zmysłu na leksykalny aspekt funkcjonowania językowego człowieka.

\section{Cel i metoda badania}

Celem eksperymentu przedstawionego w obecnej pracy jest zbadanie górnych części hierarchii wyznaczających budowę rzeczownikowej części leksykonu umysłowego u 2 grup osób: z głębokim defektem wzroku i bez takiego defektu. Cel ten zrealizowano przy pomocy analizy końcowych elementów $(\mathrm{PN})$ psychologicznych ciagów definicyjnych konstruowanych przez respondentów niewidomych i widzących. Szczegółową instrukcję badawczą oparto na rozumieniu relacji hiperonimii/hiponimii m.in. wg Lyonsa (1984) i Bańczerowskiego, Pogonowskiego i Zgółki (1982), przy użyciu często stosowanego przykładu tulipan - kwiat (por. np. Lyons 1984, Kleiber, Tamba 1990). Analiza otrzymanych danych dotyczyła:

poprawności wyników otrzymanych od obu badanych grup, rozumianej jako zgodność 974), z uporządkowaniem wiedzy zawartym w słownikach języka polskiego, stopnia ogólności wyrażeń stanowiących końcowe elementy ciągów.

Stopień ogólności oceniano przede wszystkim poprzez odniesienie do elementów nadrzędnych hierarchii z bazy WordNet. Różnice w wynikach uzyskanych od obu badanych grup traktowano jako jeden ze wskaźników wpływu doświadczeń wzrokowych na ten aspekt budowy leksykonu umysłowego.

\footnotetext{
${ }^{4}$ Autorka obecnej pracy dziękuje pani prof. Jadwidze Sambor za udostępnienie tekstu instrukcji.
} 


\section{Respondenci}

Przebadano 116 osób $^{5}$. Grupę eksperymentalną stanowiło 58 osób niewidomych w wieku 13-19 lat z klas: I - III gimnazjum, II - IV liceum ogólnokształcącego oraz II - IV szkół średnich zawodowych ${ }^{6}$. Badaniu poddano osoby całkowicie niewidome lub jedynie $\mathrm{z}$ poczuciem światła, bez zachowanych wspomnień wzrokowych (z dysfunkcją wzroku ujawnioną od urodzenia lub we wczesnych latach życia). Kryterium doboru 58-osobowej grupy kontrolnej osób widzących stanowiły: płeć, poziom i rodzaj wykształcenia oraz wyniki w nauce określane na skali: słaby, średni, dobry i bardzo dobry. Grupę kontrolną stanowiły osoby w wieku 13-18 lat: 27 osób z grupy kontrolnej jest przynajmniej o rok młodszych niż osoby niewidome $\mathrm{z}$ tego samego poziomu kształcenia (u wielu osób niewidomych występują opóźnienia w cyklu kształcenia nie związane ze słabymi wynikami w nauce).

Badania przeprowadzano w 5 Ośrodkach Szkolno-Wychowawczych dla Dzieci i Młodzieży Niewidomej i Słabowidzącej (w: Owińskach k/Poznania, Krakowie, Bydgoszczy, Laskach k/Warszawy oraz Wrocławiu) oraz w szkołach ponadpodstawowych w Poznaniu. Większość badań przeprowadzono w roku szkolnym 2001/2002, pozostałe w roku 2002/2003.

\section{Materiał badawczy i przebieg badania}

Materiał badawczy stanowi 75 polskich rzeczowników, o których założono, że są znane naiwnym użytkownikom języka polskiego. Podstawę doboru rzeczowników do korpusu stanowiły kryteria semantyczne. Wybrano rzeczowniki zróżnicowane wg dwóch kryteriów:

1) przynależność do określonych pól leksykalnych,

2) udział elementów znaczeniowych opartych wyłącznie lub głównie na spostrzeżeniach wzrokowych oraz możliwość dotykowego poznania desygnatów przez osoby niewidome.

Materiał badawczy można podzielić na 25 wymienionych poniżej 3-elementowych grup, tworzących kategorie pojęciowe wyższego rzędu, niż pojęcia odpowiadające poszczególnym rzeczownikom $\mathrm{z}$ grupy. Jako nazwy grup stosowano określenia nadrzędne uzyskane $\mathrm{w}$ dodatkowo przeprowadzonym badaniu 45 studentów filologii.

1. Drzewa: sosna, buk, brzoza

2. Owoce i warzywa: cytryna, pomidor, marchew

3. Zwierzęta: gil, lis, osa

4. Części ciała: ręka, łapa, oko

5. Ludzie: nauczyciel, egoista, biedak

6. Grupy ludzi: gang, brygada, drużyna

7. Płyny organizmu: ślina, pot, krew

8. Pożywienie: piwo, kiełbasa, ser

9. Urządzenia: komputer, telefon, pralka

10. Pojazdy: traktor, autobus, ciężarówka

11. Kosmetyki: mydło, szampon, dezodorant

12. Budynki: chata, kamienica, pałac

13. Części domu: komin, dach, okno

14. Elementy pomieszczenia: ściana, podłoga, sufit

15. Miejsca handlowo-usługowe: apteka, kawiarnia, ksiegarnia

16. Tereny: boisko, łąka, podwórze

17. Elementy krajobrazu: wzgórze, jaskinia, rzeka

18. Zjawiska atmosferyczne: tęcza, błyskawica, grad

\footnotetext{
${ }^{5}$ Badania przeprowadzono w ramach realizacji projektu KBN „Charakterystyka hierarchicznej struktury leksykonu umysłowego osób niewidomych".

${ }^{6} \mathrm{Na}$ skutek reformy szkolnictwa $\mathrm{w}$ momencie przeprowadzania badań nie było poziomu klas I średnich $\mathrm{w}$ szkolnictwie masowym. 2 uczniów niewidomych z klas I liceum ogólnokształcącego i zawodowego (klas stanowiących wyjątkowe uzupełnienie szkolnictwa osób niewidomych po reformie) potraktowano jako osoby z poziomu III klasy gimnazjum, ze względu na brak odpowiedników w zreformowanym szkolnictwie osób widzących.
} 
19. Materiały: metal, szkło, beton

20. Dzieła sztuki: symfonia, powieść, posag

21. Czas: wtorek, marzec, jesień

22. Dźwięki: wrzask, gwizd, tupot

23. Czynności: morderstwo, walka, krok

24. Emocje: radość, zdziwienie, strach

25. Cechy charakteru: lekkomyślność, uczciwość, ostrożność

Wymienione grupy będą dalej nazywane klasami semantycznymi. Klasy są niejednakowo zróżnicowane wewnętrznie. Niektóre klasy o małym wewnętrznym zróżnicowaniu można traktować jako tworzące większe pola leksykalne, np. Drzewa oraz Owoce i Warzywa to „Rośliny”, a Budynki, Pojazdy, Części domu, Elementy pomieszczenia, Urządzenia, Kosmetyki i Dzieła sztuki to „Wytwory człowieka”, do których można zaliczyć także niektóre rzeczowniki z grup: Tereny oraz Materiały.

Podział materiału na 25 małych klas lub na mniejszą liczbę grup większych pozwala na szukanie pewnych ogólnych tendencji dotyczących hierarchizacji określonych części leksykonu u osób niewidomych i widzących. Rzeczowniki wyselekcjonowane do obecnych badań można zaliczyć do przynajmniej 16 z 25 hierarchii składających się na całość sieci rzeczowników w hierarchicznej bazie leksykalnej WordNet (por. par. 1). Zatem można przyjąć, że poszczególne uwzględnione pola leksykalne reprezentują znaczną część struktury wszystkich rzeczowników w leksykonie umysłowym człowieka.

Korpus 75 rzeczowników podzielono także na 3 grupy różniące się rolą wzroku w poznaniu ich desygnatów przez człowieka widzącego (a więc wagą informacji wzrokowych w konstruowaniu przez widzących pojęć odpowiadających danym rzeczownikom). W klasyfikacji brano pod uwagę takie cechy, jak: kolor, przezroczystość i połysk desygnatów, ich wielkość (od której zależy dokładność dotykowego poznawania kształtów), dostępność (odległość, wysokość, rodzaj środowiska), postać fizyczna (gazowa, płynna lub stała o różnym stopniu twardości), możliwość jednoczesnej percepcji wzrokowej przedmiotu w porównaniu $\mathrm{z}$ sekwencyjnością poznania dotykowego.

Grupa 1: tęcza, błyskawica, rzeka, grad, lis, gil, osa, sosna, brzoza, buk, ślina, pot, krew, oko, komin, dach, ściana, sufit, piwo

Grupa 2: metal, szkło, łqka, cytryna, pomidor, marchew, chata, kamienica, pałac, traktor, autobus, ciężarówka, wzgórze, jaskinia, szampon, dezodorant, mydto, beton, ser, boisko, podwórze, apteka, kawiarnia, księgarnia, podtoga, okno, kiełbasa, komputer, telefon, pralka, posag, gang, brygada, drużyna, ręka, łapa, jesień

Grupa 3: radość, zdziwienie, strach, morderstwo, krok, walka, wrzask, gwizd, tupot, symfonia, powieśś, nauczyciel, egoista, biedak, wtorek, marzec, lekkomyślność, uczciwość, ostrożność

Grupa 1 zawiera wyrazy o wysokim udziale informacji wzrokowych, grupa 2 - wyrazy o średnim, a 3 - o niskim udziale informacji wzrokowych.

Rzeczowniki stanowiące materiał badawczy można uznać za reprezentujące kategorie z poziomu podstawowego lub ewentualnie $\mathrm{z}$ poziomu podrzędnego $\mathrm{w}$ stosunku do niego ${ }^{7}$.

Badanie miało charakter pisemny (w przypadku grupy eksperymentalnej instrukcja i odpowiedzi pisane były przy użyciu alfabetu Braille’a). Eksperyment przeprowadzono w 3 etapach, w odstępach co najmniej 2-tygodniowych. W każdym z etapów listę haseł stanowiących punkt wyjścia ciągów stanowiło 25 rzeczowników, po jednym z 25 wyodrębnionych 3elementowych grup. Otrzymano 4126 elementów PN od osób niewidomych i 3917 od osób widzących.

\footnotetext{
${ }^{7} \mathrm{O}$ przyjmowaniu w naszej kulturze gatunków drzew za pojęcia z poziomu podstawowego por. np. Habrajska 1996, lub Berlin za: Chlewiński 1999.
} 


\section{Analiza semantyczna}

\subsection{Kryteria analizy semantycznej}

Definicje leksykograficzne jako podstawa analizy. Punktem wyjścia dla określania relacji semantycznych między reakcją (elementem PN ciągu) a hasłem (elementem P0 ciagu) były znaczenia haseł podane we współczesnych słownikach języka polskiego ([SJPDor], [SJPSz], [SJPDun], $\left.[\mathrm{SJPZg}]^{8}\right)$. Celem analizy było zatem stwierdzenie, czy reakcje uzyskane od respondentów można uznać za pozostające w relacji inkluzji do hasła z punktu widzenia językoznawców, a dokładniej autorów słowników języka polskiego. Wybór takiego punktu wyjścia dla analizy semantycznej został podyktowany chęcią jej zobiektywizowania. Zastosowana metoda analizy pozwala zatem jedynie na stwierdzenie, w jakim stopniu reakcje podane przez respondentów można uznać za zgodne z hierarchizacją słownictwa rekonstruowaną na podstawie istniejących definicji leksykograficznych.

Pozostałe kryteria analizy semantycznej mają na celu ocenę reakcji pod względem ich inkluzywności z możliwie dużą tolerancją, w ramach jednak sformułowanego wyżej kryterium odniesienia do wiedzy słownikowej. Taka „zasada tolerancji” realizowana jest poprzez: ujmowanie hiponimii jako relacji o charakterze prototypowym, branie pod uwagę tych znaczeń słownikowych hasła, które pozwalają na określanie relacji hasło-reakcja jako najbardziej prawidłowej, uwzględnianie $\mathrm{w}$ analizach relacji meronimii, potraktowanie jako prawidłowe reakcji synonimicznych oraz wyodrębnienie relacji quasi-inkluzywnych.

Reakcje hiperonimiczne nieprototypowe: Relacja hiponimii ma charakter prototypowy, tzn. istnieją lepsze i gorsze jej egzemplarze (por. Cruse 2000). Niekiedy związek między wyrazami A i B jest wyznaczony prawie całkowitym zawarciem zakresu znaczeniowego A w zakresie znaczeniowym B, co może zostać odzwierciedlone w definicji leksykograficznej, np. szampon „Środek, zwykle płynny, do mycia włosów” ([SJPDun, s. 1084, podkr. autorki). Takie nieprototypowe, gorsze przykłady hiponimii określano jako oparte na typowości. Jako połączone z hasłem taką relacją traktowano także reakcje określające funkcję desygnatu hasła, por. np. traktor sprzęt rolniczy ${ }^{9}$, kawiarnia - miejsce pogawędek: uszczegółowienie szerszych hiperonimów sprzęt i miejsce wiąże się z funkcją, którą każdy desygnat odpowiednich haseł może potencjalnie pełnić. Jako gorsze egzemplarze hiponimii można klasyfikować także te, dla których trudność określenia stopnia zawierania zakresów znaczeniowych A i B wynika z relatywności znaczenia B, np. reakcja nowość na hasło komputer (określana jako hiperonim relatywny). W przypadku, gdy zbieżność zakresów hasła i reakcji jest mniejsza i nie znajduje odzwierciedlenia w słownikach, relacje określano jako quasi-hiperonimiczne (por. niżej).

Wykorzystywanie znaczeń hasła polisemicznego: Większość rzeczowników stanowiących materiał badawczy traktuje się we współczesnych słownikach języka polskiego jako posiadające kilka powiązanych ze sobą znaczeń. W analizie danej reakcji wybierano znaczenie hasła polisemicznego, które pozwala na określenie relacji hasło-reakcja jako najbardziej zgodnej z instrukcją. Np. w klasyfikacji odpowiedzi alkohol na hasło piwo nie wykorzystano znaczenia 1: „bezbarwna, palna ciecz, czynny składnik napojów odurzających...” ([SJPDun] s. 10), lecz znaczenie 2 definiowane jako: „napój zawierający tę substancję” (ibidem, s. 10). Wybór znaczenia 1 spowodowałby określenie relacji między hasłem a reakcją jako związku całość - część.

Reakcje synonimiczno-hiperonimiczne: Jako poprawne (zgodne $\mathrm{z}$ instrukcja) traktowano reakcje o zakresie znaczeniowym zbliżonym do zakresu hasła. W świetle rozważań niektórych semantyków granica między relacją synonimii a hiponimii nie jest ostra i niekiedy musi być ustalana arbitralnie. Wniosek taki wypływa m.in. ze sformułowań Grodzińskiego: „nazwy A i B tylko wówczas mogą być synonimami, jeżeli różnica zakresów jest stosunkowo niewielka, tzn. jeżeli zakres nazwy B wypełnia sobą większą część zakresu nazwy A" (Grodziński 1985, s.127). Natomiast Lyons (1984) definiuje synonimię jako hiponimię obustronną (symetryczna). Istnieje możliwość, że wyraz o charakterze synonimicznym jest uważany przez respondenta (przynajmniej w momencie badania) za w jakimś stopniu nadrzędny w stosunku do hasła (np. gang - banda czy

\footnotetext{
${ }^{8}$ Rozwiązanie skrótów nazw słowników w bibliografii.

${ }^{9}$ Przykłady podawane w tym paragrafie pochodzą z opisywanych badań.
} 
posag - figura). Zatem w przypadku, gdy definicje słownikowe hasła i reakcji wskazują na podobny zakres znaczeniowy lub są to nawet definicje tzw. synonimiczne, traktowano reakcję jako poprawną, z zaznaczeniem wszakże bliskości zakresu znaczeniowego, a więc jako tzw. reakcję synonimiczno-hiperonimiczną.

Relacja meronimii: Wiele odpowiedzi udzielonych przez badanych można było określić jako holonimy hasła. Zgodnie $\mathrm{z}$,zasadą tolerancji” posługiwano się $\mathrm{w}$ analizach szerokim ujęciem meronimii, umożliwiającym uwzględnienie różnych jej rodzajów.

Szerokie ujmowanie omawianej relacji polegało także na klasyfikowaniu jako meronimicznyh związków słabszych, tzn. nieprototypowych. Wg Cruse'a (2000) jednym z czynników wyznaczających prototypowość meronimii jest konieczność połączenia desygnatów meronimu i holonimu (na temat zróżnicowana tej konieczności w poszczególnych przypadkach meronimii por. także Saeed 1998). Relacja o charakterze prototypowym istnieje między wyrazami ręka i człowiek: z jednej strony ciało człowieka musi składać się z rąk, a z drugiej - ręka nie istnieje jako całość niezależna od ciała. Nieco słabsza zależność występuje między wyrazami nauczyciel i szkoła: szkoła (w znaczeniu: „ludzie związani z instytucją oświatową...” por. [SJPDun, s.1093] musi składać się z nauczycieli, ale człowiek pełniący zawód nauczyciela może nie być związany z żadną szkołą. Osłabienie związku meronimii może się także wiązać z czynnikiem określonym przez Cruse'a jako zgodność rangi (w hierarchii ogólności). I tak związek nieprototypowy istnieje dla przypadków typu łapa - niedźwiedź: normalnie zbudowany niedźwiedź ma łapy, a łapa jest zawsze częścią zwierzęcia, ale niekoniecznie niedźwiedzia (łapa wg terminologii Cruse'a jest tu tzw. supermeronimem). Jeszcze bardziej odległe od prototypu są przypadki typu komin - budynek: komin może istnieć jako samodzielna konstrukcja, budynek (np. stodoła) może nie zawierać komina (komin w terminologii Cruse'a jest tu tzw. semi-meronimem).

Stopień zbliżenia meronimii do prototypu może być uzależniony także od rodzaju tej relacji. Szczególnie meronimię materiał - obiekt, jako związek między różnymi kategoriami ontologicznymi, można uważać za odległą od prototypu (zgodność typów ontologicznych to kolejny wyznacznik prototypowości meronimii wg Cruse'a).

Założono także możliwość klasyfikowania jako inkluzywnej relacji między elementami o bardzo zróżnicowanych wielkościach, jak np. podłoga - Ziemia/ziemia (w znaczeniu „świat”). Takie, z pewnością kontrowersyjne, wyjście poza stricte leksykalne ujmowanie relacji meronimii spowodowane było przekonaniem, iż brak szeroko uznawanej inkluzywności leksykalnej takich elementów wynika jedynie z rzadkiej potrzeby konstruowania logicznie sensownych zdań typu: Ziemia składa się z podtóg czy Podtoga jest częściq Ziemi (por. znacznie mniej kontrowersyjną relację dom - świat). To kryterium analizy sformułowano zresztą głównie ze względu na charakter zadania: tworzenie szeregów wyrazów coraz ogólniejszych przy zastosowaniu meronimii często prowadzi do konfrontacji respondenta $\mathrm{z}$ dyskusyjnym problemem przechodniości tej relacji ${ }^{10}$. Konstruowanie ciagów typu meronimicznego może doprowadzić do takiej inkluzji dotyczącej bardziej desygnatów P0 i PN ciągu, nawet gdy meronimie między kolejnymi elementami ciągu mają charakter ściśle leksykalny.

Wątpliwości typu: meronimia czy hiponimia, wynikające głównie z wyboru odpowiedniego znaczenia (np. dla reakcji cytryna - roślina możliwość wyboru znaczeń hasła cytryna: 1. drzewo, 2. owoc, por. np.[SJPDun], s.138) rozstrzygano na korzyść hiponimii jako relacji bardziej zgodnej z instrukcją zadania.

Reakcje quasi-inkluzywne: Wiele otrzymanych odpowiedzi zbliża się, na różne sposoby, do relacji inkluzji. Chęć odróżnienia odpowiedzi tego typu od takich, które są powiązane $\mathrm{z}$ leksykograficznym znaczeniem hasła innymi niż inkluzywne relacjami, zadecydowała o wprowadzeniu klasy reakcji quasi-inkluzywnych. W oparciu o otrzymane dane wyodrębniono następujące podstawowe rodzaje reakcji quasi-hiperonimicznych w stosunku do hasła:

\footnotetext{
${ }^{10}$ Jak wspomniano w par. 1., brak przechodniości relacji meronimii może wynikać ze zmiany jej rodzaju, np. z przejścia od relacji czesść - całość do relacji element - zbiór. Wpływ takiego poglądu na ocenę słuszności klasyfikowania relacji podtoga - ziemia jako meronimicznej może zależeć od sposobu ujmowania znaczenia hasła ziemia.
} 
- Quasi-hiperonimy oparte na rozszerzeniu znaczenia: sposób użycia wyrazu przez respondenta może wykraczać nieco poza zakres wyznaczony definicjami leksykograficznymi, np. posag - wynalazek człowieka (wynalazek definiowany jest w słownikach jako rzecz wynaleziona, stworzona przez kogoś; element twórczości stanowi podstawę rozszerzenia znaczenia wyrazu na obiekty stanowiące dzieła sztuki).

- Quasi-hiperonimy oparte na koniecznych częściach lub materiale: niektóre wyrazy można sensownie definiować poprzez podawanie ich części lub materiału, z którego są zrobione, np. okno - „wypełniająca otwór...szyba, oprawiona w ramę...” ([SJPDun], s.677), Las „liczne drzewa, rosnące...” Kleik - „mąka...” (Rey-Debove 1971, s. 240, 241, tłum. N. M.M.). Definicje tego rodzaju stanowią przedmiot zainteresowań semantyków i leksykografów (por. Quemada 1968, Rey-Debove 1971, Tokarski 1987, Hammerl, Sambor 1993). Wiele reakcji respondentów w obecnych badaniach wydaje się mieć charakter początku takich definicji. Traktowano je jako quasi-hiperonimy, jeśli podana część lub materiał są niezbędne i zarazem na tyle znaczące, że mogą stać się podstawą sensownej definicji. Zatem reakcje okno - szyba i grad - lód uznano za quasi-hiperonimiczne, podczas gdy reakcje posqg - kamień i osa - żadto zaklasyfikowano jako podrzędne typu meronimicznego (posąg nie musi być wykonany z kamienia, a definicje typu osa - ,żądło z tułowiem" budzą zbyt duże zastrzeżenia). Quasi-hiperonimy wyodrębniane na omawianej zasadzie można uszeregować w zależności od stopnia zbliżenia do hiperonimii: od reakcji typu rzeka - woda czy kiełbasa - mięso, które mogłyby zostać uznane przez niektórych użytkowników języka za rzeczywiste hiperonimy, poprzez reakcje typu ślina - woda czy brygada - ludzie, aż po takie, jak piwo - chmiel czy łaka - rośliny. Utworzenie takiej klasy quasi-hiperonimów powoduje w niektórych wypadkach konieczność odrębnego traktowania reakcji w liczbie pojedynczej i mnogiej. Np. można sensownie zdefiniować take poczynając od wyrazu rośliny, a brygada - od wyrazu ludzie, podczas gdy odpowiednie reakcje w liczbie pojedynczej nie mogą pełnić takiej roli.

- Quasi-hiperonimy niepełne: w niektórych przypadkach wątpliwości co do hiperonimicznego charakteru reakcji wynikają $\mathrm{z}$ braku określenia uzupełniającego, precyzującego rodzaj jej powiązania ze znaczeniem hasła. Na przykład reakcje jesień fragment, powieść - zbiór czy błyskawica - wynik można by z dosyć dużą pewnością uznać za hiperonimy haseł po przykładowych uzupełnieniach: fragment roku, zbiór zdań, wynik wytadowania.

- Quasi-hiperonimy relatywne (por. wyżej).

Pewną liczbę reakcji określono jako quasi-holonimy oparte na rozszerzeniu znaczenia; rozszerzanie znaczenia polegało najczęściej na uznawaniu za realne nawet nietrwałych związków część - całość, np. ślina - człowiek lub lis - las.

Wyodrębnianie reakcji quasi-inkluzywnych zwiększa stopień subiektywności przeprowadzanej analizy, pozwala jednak na zróżnicowanie stopnia zbliżania się respondentów do właściwego (z punktu widzenia wiedzy zawartej w słownikach) wykonania zadania psycholingwistycznego. W niektórych przypadkach łączono przedstawione kryteria semantyczne, np. pojawiła się klasa odpowiedzi quasi-synonimiczno-hiperonimicznych (opartych na rozszerzeniu znaczenia). Decyzji semantycznych podjętych $\mathrm{w}$ ramach analizy wyników obecnego badania nie traktuje się jako rozstrzygających ani ostatecznych. 


\subsection{Porównanie prawidłowości wszystkich odpowiedzi uzyskanych od niewidomych i widzących}

Wszystkie odpowiedzi uzyskane od osób badanych z obu grup poddano analizie semantycznej wg podanych wyżej kryteriów. Następnie dla każdego z 75 haseł wyznaczono liczbę osób, które podały odpowiedzi uznane za prawidłowe (w jakimś stopniu inkluzywne), czyli hiperonimy, holonimy i quasi-hiperonimy hasła (nieliczne reakcje zakwalifikowane jako quasi-holonimy włączono do grupy holonimów, natomiast reakcje synonimiczno-hiperonimiczne liczono łącznie z hiperonimami).

Średnio około $72 \%$ osób widzących i około $67 \%$ osób niewidomych podało na jedno hasło z listy reakcje o charakterze inkluzywnym. Różnica między średnimi (mierzona testem t) jest istotna na poziomie $\alpha=0,03$. Średnio około $57 \%$ osób widzących i około $51 \%$ osób niewidomych udzieliło na jedno hasło odpowiedzi klasyfikowanej jako jego hiperonim. Różnica między średnimi (mierzona testem $\mathrm{t}$ ) jest istotna na poziomie $\alpha=0,01$. Osoby widzące przejawiły zatem nieco większą od niewidomych zdolność do podawania, jako końcowych elementów ciągów, odpowiedzi o wyższym poziomie ogólności, niż rzeczowniki stanowiące materiał badawczy.

Jednakże dla obu badanych grup podawanie reakcji inkluzywnych okazało się najłatwiejsze w odniesieniu do podobnych zbiorów haseł. Ponad 80\% osób (ponad 46 osób) z każdej grupy podało prawidłowe reakcje końcowe ciągu na przynajmniej 2 hasła z klas: Drzewa, Zwierzęta, Owoce i Warzywa, Czas i Pojazdy oraz dla hasła piwo. Dla osób widzących równie łatwe okazały się także rzeczowniki: ręka, tapa, pralka, pałac, strach i grad. Natomiast zbiory haseł, które okazały się najtrudniejsze, są odmienne dla widzących i niewidomych. Nie więcej niż $50 \%$ osób (nie więcej niż 29 osób) z grupy widzących podało reakcje uznane za poprawne na hasła: dezodorant, symfonia i posag. Nie więcej niż $50 \%$ niewidomych podało takie odpowiedzi na hasła: pot, mydto, podwórze, morderstwo, walka, komin, sufit i lekkomyślność.

Dla wszystkich haseł łatwych (tych, dla których uzyskano ponad 80\% odpowiedzi poprawnych) reakcje inkluzywne to głównie hiperonimy. Dla 6 haseł uzyskano hiperonimy od ponad $80 \%$ grupy widzących (są to hasła: brzoza, pomidor, marchew, osa, pralka i ciężarówka). Natomiast dla żadnego $\mathrm{z}$ haseł nie otrzymano hiperonimów od tak wysokiej liczby osób niewidomych.

Dla 26 haseł hiperonimy podało nie więcej niż $50 \%$ osób z każdej z badanych grup. Ponadto nie więcej niż 50\% widzących podało hiperonimy dla kolejnych 2 rzeczowników, a nie więcej niż 50\% niewidomych - dla kolejnych 14 rzeczowników.

Różnice między wielkością całego zbioru reakcji uznanych za prawidłowe a wielkością zbioru reakcji hiperonimicznych wyznacza częstość pojawiania się odpowiedzi uznawanych za holonimy i quasi-hiperonimy hasła. Niewidomi przejawiają nieznacznie silniejszą tendencję do podawania holonimów i quasi-hiperonimów zamiast hiperonimów: średnio (w przeliczeniu na jedno hasło) około $9 \%$ niewidomych i $8 \%$ widzących podało holonim; średnio około 7,5\% niewidomych i $6,5 \%$ widzących podało quasi-hiperonim.

Istnieją jednak pewne podobieństwa w tendencji do podawania holonimów w odniesieniu do określonych haseł. 5 rzeczowników nie wywołało $\mathrm{w}$ żadnej $\mathrm{z}$ grup ani jednej reakcji klasyfikowanej jako holonim. Ponadto żaden niewidomy nie podał holonimu dla 4 dodatkowych haseł (dla tych haseł najwyżej $5 \%$ widzących podało taką reakcję), a żaden widzący nie podał holonimu dla dodatkowych 8 haseł (dla tych haseł najwyżej 6\% niewidomych podało taką reakcję). Ponad 20\% osób (przynajmniej 12 osób) z każdej z grup podało holonimy dla rzeczowników: sosna, buk, wtorek, marzec, krok, ściana. Ponad 20\% niewidomych podało holonim także dla haseł: brzoza, brygada, szkło, beton, błyskawica. Natomiast ponad $20 \%$ widzących podało holonim rzeczownika komin.

Nieco mniejsze zbieżności w wynikach obu grup występują w przypadku quasi-hiperonimów. Tylko 2 rzeczowniki (tupot i egoista) nie wywołały w żadnej z grup ani jednej reakcji uznanej za quasi-hiperonim. Ponadto żaden niewidomy nie podał quasi-hiperonimu dla innych 10 haseł (dla tych haseł najwyżej 7\% widzących podało taką reakcję), a żaden widzący - dla innych 16 haseł (dla tych haseł najwyżej 7\% niewidomych podało taką reakcję). Ponad $20 \%$ osób z każdej z grup podało quasi-hiperonimy dla haseł gang i rzeka. Ponad $20 \%$ niewidomych podało quasi-hiperonim 
także dla haseł: kietbasa, drużyna, gwizd, tęcza, grad i ściana, a ponad $20 \%$ widzących - dla hasła ręka.

Przewaga widzących w podawaniu hiperonimów jest nieco wyraźniejsza w przypadku rzeczowników o znaczeniach silnie powiązanych z informacjami wzrokowymi (np. grad, brzoza, krew), niż w przypadku rzeczowników o znaczeniach słabo powiązanych z takimi informacjami. Dla niektórych rzeczowników o niskim stopniu wizualności hiperonimy podaje nawet wyraźnie więcej osób niewidomych (np. dla haseł symfonia i marzec).

\subsection{Analiza reakcji dominujących}

Dla każdego hasła wyodrębniono reakcję lub reakcje podane przez największą liczbę respondentów z każdej grupy badanych. Reakcje takie, które będą dalej nazywane dominującymi, zawiera tabela 1. W tabeli tłustą czcionką wyodrębniono odmienne reakcje dominujące podane przez dwie grupy respondentów na dane hasło. Różnice dotyczące przynajmniej jednej z odpowiedzi dominujących wystąpiły dla 40 haseł.

Tabela 1.

\begin{tabular}{|c|c|c|c|c|c|c|}
\hline \multirow{2}{*}{ hasło } & \multicolumn{3}{|c|}{ Niewidomi } & \multicolumn{3}{|c|}{ Widzący } \\
\hline & reakcje & 1. osób & relacje & reakcje & 1. osób & relacje \\
\hline $\begin{array}{l}\text { sosna } \\
\text { buk } \\
\text { brzoza }\end{array}$ & $\begin{array}{l}\text { roślina } \\
\text { roślina } \\
\text { roślina } \\
\end{array}$ & $\begin{array}{l}15 \\
21 \\
21 \\
\end{array}$ & $\begin{array}{l}\mathrm{H} \\
\mathrm{H} \\
\mathrm{H} \\
\end{array}$ & $\begin{array}{l}\text { roślina }(\mathrm{y}) \\
\text { roślina } \\
\text { roślina }\end{array}$ & $\begin{array}{l}21 \\
25 \\
24 \\
\end{array}$ & $\begin{array}{l}\mathrm{H} \\
\mathrm{H} \\
\mathrm{H} \\
\end{array}$ \\
\hline $\begin{array}{l}\text { gil } \\
\text { lis } \\
\text { osa } \\
\end{array}$ & $\begin{array}{l}\text { ptak } \\
\text { zwierzę } \\
\text { owad }\end{array}$ & $\begin{array}{l}14 \\
19 \\
21 \\
\end{array}$ & $\begin{array}{l}\mathrm{H} \\
\mathrm{H} \\
\mathrm{H} \\
\end{array}$ & $\begin{array}{l}\text { zwierzę } \\
\text { zwierzę (ta) } \\
\text { owad }\end{array}$ & $\begin{array}{l}11 \\
15 \\
16\end{array}$ & $\begin{array}{l}\mathrm{H} \\
\mathrm{H} \\
\mathrm{H}\end{array}$ \\
\hline $\begin{array}{l}\text { cytryna } \\
\text { pomidor } \\
\text { marchew } \\
\end{array}$ & $\begin{array}{l}\text { Owoc } \\
\text { warzywo, roślina } \\
\text { warzywo } \\
\end{array}$ & $\begin{array}{l}14 \\
15 \\
16 \\
\end{array}$ & $\begin{array}{c}\mathrm{H} \\
\mathrm{H}, \mathrm{H} \\
\mathrm{H} \\
\end{array}$ & $\begin{array}{l}\text { owoc } \\
\text { roślina }(y) \\
\text { roślina } \\
\end{array}$ & $\begin{array}{l}18 \\
20 \\
18 \\
\end{array}$ & $\begin{array}{l}\mathrm{H} \\
\mathrm{H} \\
\mathrm{H} \\
\end{array}$ \\
\hline $\begin{array}{l}\text { wtorek } \\
\text { marzec } \\
\text { jesień } \\
\end{array}$ & $\begin{array}{l}\text { dzień } \\
\text { miesiąc } \\
\text { pora roku }\end{array}$ & $\begin{array}{l}12 \\
23 \\
24 \\
\end{array}$ & $\begin{array}{l}\mathrm{H} \\
\mathrm{H} \\
\mathrm{H}\end{array}$ & $\begin{array}{l}\text { rok (lata) } \\
\text { rok } \\
\text { pora roku (pory) } \\
\end{array}$ & $\begin{array}{c}8 \\
10 \\
24 \\
\end{array}$ & $\begin{array}{c}\mathrm{M}+ \\
\mathrm{M}+ \\
\mathrm{H}\end{array}$ \\
\hline $\begin{array}{l}\text { komputer } \\
\text { telefon } \\
\text { pralka } \\
\end{array}$ & $\begin{array}{l}\text { urządzenie } \\
\text { urządzenie } \\
\text { urządzenie }\end{array}$ & $\begin{array}{c}9 \\
8 \\
17 \\
\end{array}$ & $\begin{array}{l}\mathrm{H} \\
\mathrm{H} \\
\mathrm{H} \\
\end{array}$ & $\begin{array}{l}\text { maszyna } \\
\text { urządzenie } \\
\text { maszyna }(\mathbf{y}) \\
\end{array}$ & $\begin{array}{c}9 \\
9 \\
16 \\
\end{array}$ & $\begin{array}{l}\mathrm{H} \\
\mathrm{H} \\
\mathrm{H} \\
\end{array}$ \\
\hline $\begin{array}{l}\text { ręka } \\
\text { łapa } \\
\text { oko } \\
\end{array}$ & $\begin{array}{l}\text { część ciała } \\
\text { część ciała } \\
\text { część ciała } \\
\end{array}$ & $\begin{array}{l}15 \\
10 \\
11 \\
\end{array}$ & $\begin{array}{l}\mathrm{H} \\
\mathrm{H} \\
\mathrm{H} \\
\end{array}$ & $\begin{array}{l}\text { część ciała } \\
\text { część ciała } \\
\text { część ciała }\end{array}$ & $\begin{array}{l}13 \\
15 \\
13 \\
\end{array}$ & $\begin{array}{l}\mathrm{H} \\
\mathrm{H} \\
\mathrm{H} \\
\end{array}$ \\
\hline $\begin{array}{l}\text { chata } \\
\text { kamienica } \\
\text { pałac } \\
\end{array}$ & $\begin{array}{l}\text { budynek } \\
\text { budynek } \\
\text { budowla, budynek }\end{array}$ & $\begin{array}{l}11 \\
10 \\
10 \\
\end{array}$ & $\begin{array}{l}\mathrm{H} \\
\mathrm{H} \\
\mathrm{H} \\
\end{array}$ & $\begin{array}{l}\text { budynek } \\
\text { budynek } \\
\text { budynek } \\
\end{array}$ & $\begin{array}{l}14 \\
14 \\
16 \\
\end{array}$ & $\begin{array}{l}\mathrm{H} \\
\mathrm{H} \\
\mathrm{H} \\
\end{array}$ \\
\hline $\begin{array}{l}\text { piwo } \\
\text { kiełbasa } \\
\text { ser } \\
\end{array}$ & $\begin{array}{l}\text { alkohol } \\
\text { mięso } \\
\text { jedzenie } \\
\end{array}$ & $\begin{array}{c}12 \\
11 \\
9 \\
\end{array}$ & $\begin{array}{c}\mathrm{H} \\
? \mathrm{H} \mathrm{CZ} \\
\mathrm{H} \\
\end{array}$ & $\begin{array}{l}\text { napój } \\
\text { jedzenie } \\
\text { jedzenie }\end{array}$ & $\begin{array}{l}15 \\
10 \\
11 \\
\end{array}$ & $\begin{array}{l}\mathrm{H} \\
\mathrm{H} \\
\mathrm{H} \\
\end{array}$ \\
\hline $\begin{array}{l}\text { apteka } \\
\text { kawiarnia } \\
\text { księgarnia }\end{array}$ & $\begin{array}{l}\text { budynek } \\
\text { budynek } \\
\text { budynek }\end{array}$ & $\begin{array}{c}8 \\
12 \\
14\end{array}$ & $\begin{array}{c}\text { H } \\
\text { H TYP } \\
\text { LOK } \\
\text { H }\end{array}$ & $\begin{array}{l}\text { miejsce } \\
\text { miejsce } \\
\text { budynek }\end{array}$ & $\begin{array}{c}7 \\
12 \\
11\end{array}$ & $\begin{array}{l}\mathrm{H} \\
\mathrm{H} \\
\mathrm{H}\end{array}$ \\
\hline $\begin{array}{l}\text { ślina } \\
\text { pot } \\
\text { krew } \\
\end{array}$ & $\begin{array}{l}\text { ciecz } \\
\text { ciecz } \\
\text { ciecz } \\
\end{array}$ & $\begin{array}{c}9 \\
7 \\
11 \\
\end{array}$ & $\begin{array}{l}\mathrm{H} \\
\mathrm{H} \\
\mathrm{H}\end{array}$ & $\begin{array}{l}\text { substancja } \\
\text { wydzielina } \\
\text { płyn } \\
\end{array}$ & $\begin{array}{c}7 \\
8 \\
14 \\
\end{array}$ & $\begin{array}{l}\mathrm{H} \\
\mathrm{H} \\
\mathrm{H}\end{array}$ \\
\hline $\begin{array}{l}\text { traktor } \\
\text { autobus } \\
\text { ciężarówka }\end{array}$ & $\begin{array}{l}\text { pojazd } \\
\text { pojazd } \\
\text { pojazd }\end{array}$ & $\begin{array}{l}12 \\
23 \\
12 \\
\end{array}$ & $\begin{array}{l}\mathrm{H} \\
\mathrm{H} \\
\mathrm{H}\end{array}$ & $\begin{array}{l}\text { maszyna }(\mathbf{y}), \text { pojazd } \\
\text { pojazd } \\
\text { pojazd }\end{array}$ & $\begin{array}{l}12 \\
14 \\
22 \\
\end{array}$ & $\begin{array}{c}\mathrm{H}, \mathrm{H} \\
\mathrm{H} \\
\mathrm{H}\end{array}$ \\
\hline
\end{tabular}




\begin{tabular}{|c|c|c|c|c|c|c|}
\hline \multirow{2}{*}{ hasło } & \multicolumn{3}{|c|}{ Niewidomi } & \multicolumn{3}{|c|}{ Widzący } \\
\hline & reakcje & 1. osób & relacje & reakcje & 1. osób & relacje \\
\hline $\begin{array}{l}\text { gang } \\
\text { brygada } \\
\text { drużyna }\end{array}$ & $\begin{array}{l}\text { mafia } \\
\text { grupa } \\
\text { ludzie }\end{array}$ & $\begin{array}{l}6 \\
8 \\
8\end{array}$ & $\begin{array}{l}\text { ? S/H } \\
\text { H } \\
? \mathrm{H} \mathrm{CZ}\end{array}$ & $\begin{array}{l}\text { ludzie, mafia } \\
\text { grupa } \\
\text { grupa }\end{array}$ & $\begin{array}{c}5 \\
11 \\
9\end{array}$ & $\begin{array}{c}\text { ? H CZ, } \\
? \mathrm{~S} / \mathrm{H} \\
\mathrm{H} \\
\mathrm{H}\end{array}$ \\
\hline $\begin{array}{l}\text { nauczyciel } \\
\text { egoista } \\
\text { biedak }\end{array}$ & $\begin{array}{l}\text { człowiek (ludzie) } \\
\text { człowiek } \\
\text { człowiek }\end{array}$ & $\begin{array}{l}15 \\
18 \\
22\end{array}$ & $\begin{array}{l}\mathrm{H} \\
\mathrm{H} \\
\mathrm{H}\end{array}$ & $\begin{array}{l}\text { człowiek } \\
\text { człowiek } \\
\text { człowiek }\end{array}$ & $\begin{array}{c}8 \\
11 \\
9\end{array}$ & $\begin{array}{l}\mathrm{H} \\
\mathrm{H} \\
\mathrm{H}\end{array}$ \\
\hline $\begin{array}{l}\text { mydło } \\
\text { szampon } \\
\text { dezodorant }\end{array}$ & $\begin{array}{l}\text { kosmetyk } \\
\text { kosmetyk } \\
\text { kosmetyk (i) }\end{array}$ & $\begin{array}{c}5 \\
11 \\
15\end{array}$ & $\begin{array}{l}\mathrm{H} \\
\mathrm{H} \\
\mathrm{H}\end{array}$ & $\begin{array}{l}\text { czystość } \\
\text { substancja } \\
\text { zapach }\end{array}$ & $\begin{array}{l}5 \\
6 \\
9\end{array}$ & $\begin{array}{l}- \\
\mathrm{H} \\
\mathrm{C}\end{array}$ \\
\hline $\begin{array}{l}\text { symfonia } \\
\text { powieść } \\
\text { posag } \\
\end{array}$ & $\begin{array}{l}\text { muzyka } \\
\text { książka } \\
\text { rzeźba }\end{array}$ & $\begin{array}{c}11 \\
9 \\
9 \\
\end{array}$ & $\begin{array}{l}\mathrm{H} \\
\mathrm{H} \\
\mathrm{H} \\
\end{array}$ & $\begin{array}{l}\text { muzyka } \\
\text { książka } \\
\text { rzeźba }\end{array}$ & $\begin{array}{c}12 \\
15 \\
7 \\
\end{array}$ & $\begin{array}{l}\mathrm{H} \\
\mathrm{H} \\
\mathrm{H} \\
\end{array}$ \\
\hline $\begin{array}{l}\text { metal } \\
\text { szkło } \\
\text { beton }\end{array}$ & $\begin{array}{l}\text { tworzywo } \\
\text { substancja } \\
\text { materiał } \\
\text { budowlany, } \\
\text { cement }\end{array}$ & $\begin{array}{l}6 \\
5 \\
4\end{array}$ & $\begin{array}{c}\mathrm{H} \\
\mathrm{H} \\
\mathrm{H} \\
\text { ?H CZ }\end{array}$ & $\begin{array}{l}\text { pierwiastek } \\
\text { substancja } \\
\text { materiał budowlany, } \\
\text { substancja }\end{array}$ & $\begin{array}{l}6 \\
6 \\
4\end{array}$ & $\begin{array}{l}\mathrm{H} \\
\mathrm{H} \\
\mathrm{H} \\
\mathrm{H}\end{array}$ \\
\hline $\begin{array}{l}\text { radość } \\
\text { zdziwienie } \\
\text { strach }\end{array}$ & $\begin{array}{l}\text { uczucie (a) } \\
\text { zaskoczenie } \\
\text { uczucie }\end{array}$ & $\begin{array}{l}16 \\
11 \\
17\end{array}$ & $\begin{array}{c}\mathrm{H} \\
\mathrm{S} / \mathrm{H} \\
\mathrm{H}\end{array}$ & $\begin{array}{l}\text { uczucie (a) } \\
\text { uczucie, reakcja } \\
\text { uczucie (a) }\end{array}$ & $\begin{array}{c}26 \\
6 \\
21\end{array}$ & $\begin{array}{c}\mathrm{H} \\
\mathrm{H}, \mathrm{H} \\
\mathrm{H}\end{array}$ \\
\hline $\begin{array}{l}\text { boisko } \\
\text { ląka } \\
\text { podwórze }\end{array}$ & $\begin{array}{l}\text { plac } \\
\text { przyroda } \\
\text { przestrzeń, plac }\end{array}$ & $\begin{array}{l}7 \\
6 \\
6\end{array}$ & $\begin{array}{c}\mathrm{H} \\
\mathrm{M}+ \\
\mathrm{H}, \mathrm{H}\end{array}$ & $\begin{array}{l}\text { plac } \\
\text { przestrzeń } \\
\text { miejsce }\end{array}$ & $\begin{array}{l}6 \\
7 \\
8\end{array}$ & $\begin{array}{l}\mathrm{H} \\
\mathrm{H} \\
\mathrm{H}\end{array}$ \\
\hline $\begin{array}{l}\text { morderstwo } \\
\text { walka } \\
\text { krok }\end{array}$ & $\begin{array}{l}\text { śmierć } \\
\text { wojna } \\
\text { ruch }\end{array}$ & $\begin{array}{c}10 \\
7 \\
10 \\
\end{array}$ & $\begin{array}{c}\mathrm{SK} \\
\mathrm{S} / \mathrm{H} \\
\mathrm{H} \\
\end{array}$ & $\begin{array}{l}\text { przestępstwo } \\
\text { wojna } \\
\text { ruch } \\
\end{array}$ & $\begin{array}{c}10 \\
4 \\
15 \\
\end{array}$ & $\begin{array}{c}\mathrm{H} \\
\mathrm{S} / \mathrm{H} \\
\mathrm{H}\end{array}$ \\
\hline $\begin{array}{l}\text { wrzask } \\
\text { gwizd } \\
\text { tupot }\end{array}$ & $\begin{array}{l}\text { hałas } \\
\text { dźwięk, hałas } \\
\text { odgłos }\end{array}$ & $\begin{array}{l}10 \\
12 \\
11\end{array}$ & $\begin{array}{c}\mathrm{H} \\
\mathrm{H}, ? \mathrm{H} \\
\mathrm{REL} \\
\mathrm{H}\end{array}$ & $\begin{array}{l}\text { dźwięk (i) } \\
\text { dźwięk } \\
\text { hałas }\end{array}$ & $\begin{array}{l}15 \\
12 \\
11\end{array}$ & $\begin{array}{c}\mathrm{H} \\
\mathrm{H} \\
\mathrm{H} \text { REL }\end{array}$ \\
\hline $\begin{array}{l}\text { komin } \\
\text { dach } \\
\text { okno }\end{array}$ & $\begin{array}{l}\text { dom } \\
\text { dom } \\
\text { otwór }\end{array}$ & $\begin{array}{l}5 \\
5 \\
4\end{array}$ & $\begin{array}{c}\mathrm{M}+ \\
\mathrm{M}+ \\
\mathrm{H}\end{array}$ & $\begin{array}{l}\text { budowla } \\
\text { dom, pokrycie, część } \\
\text { budynku, część domu } \\
\text { szkło }\end{array}$ & $\begin{array}{l}6 \\
4 \\
6\end{array}$ & $\begin{array}{c}\text { ?H SZ ZN } \\
\text { lub M+ } \\
\mathrm{M}+, \mathrm{H}, \mathrm{H}, \\
\mathrm{H} \\
\text { ?H CZ }\end{array}$ \\
\hline $\begin{array}{l}\text { tęcza } \\
\text { błyskawica } \\
\text { grad }\end{array}$ & $\begin{array}{l}\text { zjawisko } \\
\text { burza } \\
\text { deszcz (e) }\end{array}$ & $\begin{array}{c}6 \\
11 \\
5\end{array}$ & $\begin{array}{c}\mathrm{H} \\
\mathrm{M}+ \\
\mathrm{KH}\end{array}$ & \begin{tabular}{|l} 
zjawisko \\
burza, zjawisko \\
zjawisko \\
atmosferyczne
\end{tabular} & $\begin{array}{l}6 \\
4 \\
9\end{array}$ & $\begin{array}{c}\mathrm{H} \\
\mathrm{M}+\mathrm{H} \\
\mathrm{H}\end{array}$ \\
\hline $\begin{array}{l}\text { wzgórze } \\
\text { jaskinia } \\
\text { rzeka }\end{array}$ & $\begin{array}{l}\text { góra } \\
\text { grota } \\
\text { woda } \\
\end{array}$ & $\begin{array}{c}8 \\
7 \\
16 \\
\end{array}$ & $\begin{array}{c}\mathrm{H} \\
\mathrm{S} / \mathrm{H} \\
? \mathrm{H} \mathrm{CZ} \\
\end{array}$ & $\begin{array}{l}\text { góra }(y) \\
\text { dziura } \\
\text { woda } \\
\end{array}$ & $\begin{array}{c}9 \\
6 \\
23 \\
\end{array}$ & $\begin{array}{c}\mathrm{H} \\
\mathrm{H} \\
? \mathrm{H} \mathrm{CZ} \\
\end{array}$ \\
\hline $\begin{array}{l}\text { ściana } \\
\text { podłoga } \\
\text { sufit }\end{array}$ & $\begin{array}{l}\text { mur } \\
\text { płaszczyzna } \\
\text { dach }\end{array}$ & $\begin{array}{c}12 \\
4 \\
6 \\
\end{array}$ & $\begin{array}{c}\text { ?S/H } \\
\mathrm{H} \\
\mathrm{KH}\end{array}$ & $\begin{array}{l}\text { budynek } \\
\text { ziemia } \\
\text { dach, strop } \\
\end{array}$ & $\begin{array}{l}7 \\
4 \\
5 \\
\end{array}$ & $\begin{array}{c}\mathrm{M}+ \\
\mathrm{M}+ \\
\mathrm{KH}, \mathrm{S} / \mathrm{H}\end{array}$ \\
\hline $\begin{array}{l}\text { lekkomyślność } \\
\text { uczciwość } \\
\text { ostrożność }\end{array}$ & $\begin{array}{l}\text { głupota } \\
\text { cecha } \\
\text { cecha }\end{array}$ & $\begin{array}{c}10 \\
10 \\
7\end{array}$ & $\begin{array}{c}\mathrm{KH} \\
\mathrm{H} \\
\mathrm{H}\end{array}$ & $\begin{array}{l}\text { cecha }(\mathbf{y}) \text { charakteru } \\
\text { cecha } \\
\text { cecha }\end{array}$ & $\begin{array}{l}5 \\
9 \\
7\end{array}$ & $\begin{array}{l}\mathrm{H} \\
\mathrm{H} \\
\mathrm{H}\end{array}$ \\
\hline
\end{tabular}

Wyjaśnienie skrótów oznaczajacych relacje

Relacje inkluzywne: H - hiperonim, H TYP LOK - hiperonim oparty na typowości miejsca, H REL hiperonim relatywny, $S / H$ - reakcja synonimiczno-hiperonimiczna, $M+-$ holonim, ?H $S Z Z N$, ?H CZ, ?H REL - quasi-hiperonim: oparty na rozszerzeniu znaczenia, na koniecznych cześciach lub materiale, relatywny. Oznaczone relacje nieinkluzywne: $K H$ - kohiponim, $C$ - cecha, SK-skutek. 
Siła reakcji dominujących: Siła reakcji dominujących, wyrażona liczbą osób badanych dających takie reakcje, jest stosunkowo niska - w żadnej z badanych grup i dla żadnego hasła nie osiagnęła wartości 50\% (29 osób). Porównanie wartości median $(\mathrm{N}-11, \mathrm{~W}-10)$ oraz średnich liczb osób dających odpowiedź dominującą w przeliczeniu na jedno hasło $(\mathrm{N}-11,29, \mathrm{~W}-11,28)$ wskazuje na bardzo podobną średnią siłę reakcji w obu badanych grupach. Przynajmniej 30\% osób (przynajmniej 18 osób) dało reakcję dominującą: w grupie niewidomych dla 9 haseł, a w grupie osób widzących - dla 11 haseł (dla haseł buk, brzoza i jesień reakcje uzyskane od każdej z grup osiągnęły próg 30\%). Z kolei mniej niż 10\% (mniej niż 6 osób) dało reakcję dominującą: w grupie niewidomych dla 8 haseł, a w grupie osób widzących - dla 7 haseł (dla haseł mydto, beton i dach progu $10 \%$ nie osiagnęly reakcje otrzymane od żadnej z grup). W obu grupach stosunkowo wysoką siłę mają reakcje dominujące z klasy Drzewa, a bardzo niską - z klasy Części budynku, Materiały i Tereny.

Reakcje identyczne: Jednakowe reakcje dominujące od obu grup uzyskano na 44 hasła, co stanowi prawie dwie trzecie materiału badawczego. W przypadku 39 haseł takie identyczne odpowiedzi zakwalifikowano jako hiperonimy. Reakcje otrzymane na 4 z pozostałych 5 haseł również określono jako inkluzywne, czyli: holonimy dach - dom (meronimia część - całość) i błyskawica - burza (specyficzna odmiana meronimii część - całość), reakcja quasi-synonimicznohiperonimiczna gang - mafia oraz quasi-hiperonim rzeka - woda. Jedyną wspólną dla obu grup reakcją dominującą nieinkluzywną jest odpowiedź dach na hasło sufit.

Reakcje dominujące wspólne dla obu grup porównano pod względem poziomu ogólności z listą rzeczowników stanowiących elementy nadrzędne 25 zhierarchizowanych pól leksykalnych w bazie leksykalnej WordNet (por. par.1). Niektóre z uzyskanych reakcji osiąają poziom ogólności porównywalny $\mathrm{z}$ tymi nadrzędnymi elementami hierarchii, a mianowicie: zwierze, roślina, człowiek, grupa, jedzenie, uczucie, cecha, substancja. Nie ma natomiast wśród reakcji dominujących wspólnych odpowiedzi typu: czas, proces, działanie, obiekt naturalny czy np. przedmiot użytkowy lub przedmiot materialny (polski wyraz artefakt - dokładny odpowiednik angielskiego artifact, jest zbyt mało znany przeciętnemu użytkownikowi języka). Jedynie reakcję zjawisko na hasło tęcza można uznać za wyraz o zakresie szerszym niż nadrzędny element odpowiedniej hierarchii - zjawisko naturalne (natural phenomenon). Zatem reakcji dominujących uzyskanych od obu badanych grup nie cechuje zbyt wysoka ogólność.

Porównanie reakcji odmiennych: Dla 38 haseł uzyskano od jednej z badanych grup przynajmniej jedną reakcję dominującą odmienną niż od drugiej grupy (zarówno w grupie niewidomych, jak i widzących na kilka haseł otrzymano więcej niż jedną reakcję dominująca). Od grupy niewidomych otrzymano przynajmniej jedną reakcję inną, niż od widzących, dla 35 haseł, przy czym w większości (dla 25 haseł) są to reakcje zakwalifikowane jako hiperonimy. W przypadku kolejnych 7 haseł odpowiedzi potraktowano również jako inkluzywne -2 jako holonimy i 5 jako quasi-hiperonimy. Jedynie w przypadku 3 haseł reakcje otrzymane tylko od niewidomych uznano za nieinkluzywne: grad - deszcz(e) i lekkomyślność - głupota (kohiponimy) oraz morderstwo - śmierć (skutek). Natomiast od osób widzących uzyskano przynajmniej jedną odpowiedź odmienną, niż od niewidomych, dla 37 haseł, a w tym jako hiperonimy potraktowano odpowiedź na 28 haseł, 4 reakcje zakwalifikowano jako holonimy haseł, 2 jako quasi-hiperonimy, a jedną jako holonim lub quasi-hiperonim (komin - dach). Wreszcie odpowiedzi na dwa hasła uznano za nieinkluzywne: mydto - czystość oraz dezodorant - zapach. Zatem można uznać, że odmienne reakcje dominujące podawane przez niewidomych i widzących są w jednakowym stopniu prawidłowe.

Jednakże istnieją różnice w poziomie ogólności hiperonimów podanych przez osoby niewidome i widzące. Dla 17 haseł uzyskano od każdej z grup odmienne reakcje hiperonimiczne. W przypadku 9 takich haseł hiperonimy podane przez niewidomych można uznać za mniej ogólne (jako pierwsza podawana będzie reakcja niewidomych): gil - ptak a zwierzę; marchew - warzywo a roślina; piwo -alkohol a napój; apteka - budynek a miejsce; kawiarnia - budynek a miejsce; ślina - ciecz a substancja; szampon - kosmetyk a substancja; podwórze - przestrzeń, plac a miejsce; wrzask hatas a dźwięk(i). W kolejnych 2 przypadkach reakcje niewidomych uznano za synonimicznohiperonimiczne, a widzących - za hiperonimiczne: zdziwienie - zaskoczenie a uczucie oraz reakcja, 
jaskinia - grota a dziura. Tylko w 1 przypadku wyraźnie szerszy zakres ma odpowiedź niewidomych: tupot - odgłos a hałas. Dla hasła krew od obu grup uzyskano odpowiedzi o tej samej ogólności: ciecz i ptyn. Dla pozostałych 4 haseł z omawianego zbioru 17 dość trudno jest porównać ogólność reakcji niewidomych i widzących: metal - tworzywo a pierwiastek; pot - ciecz a wydzielina; komputer i pralka - urzadzenie a maszyna $(y)^{11}$.

O wyższej ogólności odpowiedzi udzielonych przez osoby widzące można wnioskować także na podstawie reakcji na hasło pomidor: obok wspólnej dla obu grup reakcji roślina $\mathrm{w}$ grupie niewidomych pojawia się dodatkowa, węższa reakcja warzywo.

Podobną tendencję można zauważyć także przy uwzględnianiu reakcji nie zakwalifikowanych jako hiperonimy. Podany przez niewidomych quasi-hiperonim oparty na koniecznych częściach lub materiale stanowi niekiedy hiponim reakcji podanej przez widzących: kietbasa-mięso a jedzenie; beton - cement a substancja. Z 2 holonimów stanowiących reakcję na hasło komin nieco większą ogólnością cechuje się ten podany przez widzących (budowla). Jako szersze znaczeniowo można traktować także reakcje widzących: grad - zjawisko atmosferyczne i lekkomyślność - cecha charakteru w stosunku do kohiponimicznych reakcji niewidomych, odpowiednio: deszcz i gtupota. Przejawem dążenia do ogólności może być również reakcja widzących rok na hasła wtorek i marzec, mniej zgodna z instrukcja, niż odpowiednie reakcje niewidomych: dzień i miesiac.

Wszystkie reakcje: Ogólnie przynajmniej 1 reakcja dominująca hiperonimiczna została podana przez niewidomych dla 62 haseł, a przez widzących - dla 65 haseł. Niewidomi udzielili odpowiedzi uznanych za nieinkluzywne jedynie w przypadku 4, a widzący - w przypadku 3 haseł (te nieliczne odpowiedzi nieinkluzywne to przeważnie reakcje różnicujące dwie grupy badanych). Zatem dla obu grup najsilniejsze, dominujące reakcje można uznać za zgodne $\mathrm{z}$ wiedzą zawartą $\mathrm{w}$ słownikach. Jednakże reakcje podawane przez widzących cechuje wyższy poziom ogólności.

Reakcje respondentów widzących okazały się bardziej zgodne $\mathrm{z}$ instrukcją niż reakcje niewidomych, dla 4 z 19 haseł o znaczeniu silnie opartym na danych wzrokowych (grupa $1 \mathrm{z}$ podziału w par. 3.) i dla 2 z 19 haseł z grupy o słabym powiązaniu z informacjami wzrokowymi (z grupy 3). Zależność odwrotna zachodzi dla 2 haseł z grupy 3, nie zachodzi natomiast dla żadnego hasła $\mathrm{z}$ grupy 1.

\subsection{Analiza reakcji częstych}

Dla każdej z badanych grup osób wyodrębniono odpowiedzi określane tutaj arbitralnie jako częste, tzn. podane przez przynajmniej 3 respondentów (przez ponad 5\% grupy). Poniżej zamieszczono zestawienie wyników analizy semantycznej tych reakcji, dotyczące: sumy (dla wszystkich haseł) reakcji wspólnych dla obu grup i sumy reakcji odmiennych dla każdej z grup, z podziałem na odpowiedzi prawidłowe ( $\mathrm{P}$ - czyli hiperonimy, holonimy, quasi-hiperonimy i quasi-holonimy) i nieprawidłowe (NP). Sumy obejmują także reakcje dominujące.

\begin{tabular}{cccccc}
\multicolumn{2}{c}{ Suma reakcji wspólnych } & \multicolumn{2}{c}{ Suma reakcji podanych tylko przez } & \multicolumn{2}{c}{ Suma reakcji podanych tylko przez } \\
& & \multicolumn{2}{c}{ niewidomych } & widzących \\
P & NP & P & NP & P & NP \\
181 & 11 & 80 & 23 & 127 & 17
\end{tabular}

Jak wynika z zestawienia, niewidomi i widzący podają wiele jednakowych reakcji częstych. Suma wszystkich takich reakcji wspólnych przewyższa sumę reakcji uzyskanych tylko od niewidomych bądź tylko od widzących. Jednakowe reakcje podane przez respondentów są zazwyczaj prawidłowe - suma wszystkich wspólnych reakcji prawidłowych przewyższa wielokrotnie liczbę nieprawidłowych. Stwierdzono także, iż w przypadku reakcji odmiennych przewaga reakcji prawidłowych silniejsza jest w grupie widzących: suma reakcji prawidłowych

11 W słownikach języka polskiego definicje maszyny i urzqdzenia cechuje cyrkularność: maszyna „urządzenie składające się z [...] mechanizmów...“ ([SJPDun, s. 501), urządzenie - „mechanizm bądź zespół mechanizmów...“ (ibidem, s. 1188), mechanizm - układ powiązanych ze sobą części maszyny...” (ibidem, s. 504). Wg opinii autorki obecnej pracy szerszy zakres ma wyraz urzqdzenie. 
otrzymanych tylko od widzących przewyższa ponad siedmiokrotnie sumę otrzymanych tylko od nich odpowiedzi nieprawidłowych.

Stwierdzono, iż w przypadku rzeczowników o znaczeniu najsilniej opartym na danych wzrokowych (grupa $1 \mathrm{z}$ klasyfikacji w par. 3.) wystąpiło ponad dwukrotnie więcej reakcji nieprawidłowych uzyskanych tylko od niewidomych, niż tylko od widzących (reakcji takich jest jednak niewiele). Natomiast dla rzeczowników najsłabiej związanych ze wzrokiem (grupa 3) przewaga reakcji nieprawidłowych uzyskanych tylko od niewidomych jest nieco mniejsza.

Stopień ogólności reakcji prawidłowych wspólnych: Większość (ponad 150) reakcji identycznych prawidłowych uznano za hiperonimy haseł. Kilka z nich nie stanowi hiperonimów prototypowych, np. metal - ciato state (prawie wszystkie metale $\mathrm{w}$ temperaturach typowych dla środowiska życia człowieka są ciałami stałymi) czy zdziwienie - zaskoczenie (reakcja synonimiczno-hiperonimiczna).

Dla 22 haseł przynajmniej jeden częsty (ale nie dominujący) hiperonim wspólny uznano za bardziej ogólny, niż hiperonim lub hiperonimy stanowiące reakcje dominujące (wspólne lub odmienne dla badanych grup) na dane hasło (por. reakcje z Tabeli 1). Poniżej znajduje się zestawienie takich ogólnych hiperonimów częstych (kolejność jak w Tabeli 1):

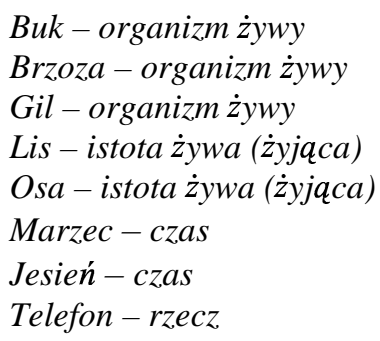

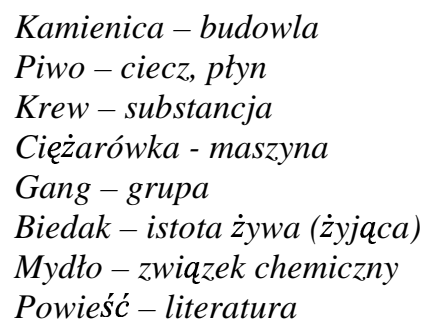

\author{
Boisko - przestrzeń, miejsce \\ Morderstwo - czyn, zło \\ Grad-zjawisko \\ Góra - wzniesienie, uksztattowanie \\ terenu \\ Sufit - ptaszczyzna \\ Lekkomyślność - cecha
}

Jak wynika $\mathrm{z}$ zestawienia, przy uwzględnieniu reakcji podanych przez przynajmniej 3 respondentów z każdej grupy zwiększa się liczba haseł, dla których uzyskano hiperonimy równorzędne elementom nadrzędnym z hierarchii bazy leksykalnej WordNet: dla kolejnych kilku haseł pojawiły się określenia cecha i substancja, ponadto wystapiła dla 2 haseł reakcja czas. Natomiast reakcje: istota żywa, organizm żywy oraz rzecz przewyższają swoją ogólnością terminy znajdujące się na szczycie hierarchii bazy WordNet.

Dla 6 z 11 haseł, w przypadku których hiperonimy dominujące podane przez widzących mają szerszy zakres, niż hiperonimy podane przez niewidomych (por. par. poprzedni), uzyskano od respondentów niewidomych reakcje częste identyczne z tymi najsilniejszymi odpowiedziami widzących. Zatem pewne hiperonimy o dość wysokim poziomie ogólności występują u niewidomych, lecz nie mają charakteru reakcji dominujących.

Pozostałe odpowiedzi prawidłowe wspólne dla obu grup to holonimy oraz quasi-hiperonimy. Zastępowanie hiponimii relacją część - całość prowadzi do poszukiwania ogólności nie poprzez wyrazy o szerokich zakresach znaczeniowych, lecz poprzez wyrazy desygnujące duże całości (przestrzenne, czasowe, liczbowe itp.). Całości desygnowane przez holonimy wspólne dla obu grup nie są jednak zbyt duże, por. np. sosna - las; komin-dom; komin-budowla; dach-dom; ściana - budynek; wtorek - rok; krok - chód; błyskawica - burza.

Spośród wspólnych quasi-hiperonimów największą grupę stanowią te oparte na koniecznych częściach lub materiale. Stosowanie wyrazów o szerokich zakresach znaczeniowych jako quasihiperonimów tego rodzaju obniżałoby precyzję definicji, których hipotetyczny początek stanowią (por. kryteria analizy semantycznej). Możliwy przykład takiej definicji: rzeka - „substancja płynąca..."

Ogólność wspólnych quasi-hiperonimów nie jest zbyt wysoka: kietbasa-mięso; ślina - woda; gang, brygada, drużyna - ludzie; okno - szyba; okno - szkło; rzeka - woda; rzeka-ciecz.

Porównanie stopnia ogólności reakcji odmiennych: Większość reakcji częstych prawidłowych podanych tylko przez niewidomych bądź tylko przez widzących zakwalifikowano jako hiperonimy. 
Dla 12 haseł przynajmniej 1 hiperonim podany tylko przez widzących cechuje większa ogólność, niż hiperonimy podane tylko przez niewidomych: sosna - drzewo ${ }^{12}$ a organizm żywy, organizm, materia; cytryna - organizm żywy a organizm; wtorek - doba a czas; marzec - część roku a okres czasu; pałac - dom a miejsce; traktor - ciqgnik, maszyna rolnicza a urzqdzenie; autobus - środek lokomocji a rzecz; zdziwienie - odczucie a stan; strach - odczucie a stan; tqka - pastwisko a teren; btyskawica - światto a zjawisko fizyczne; jaskinia - otwór a miejsce. Sytuacja odwrotna zachodzi najwyżej dla 5 haseł: telefon - przedmiot ${ }^{13}$ a maszyna, środek przekazu; pralka - przedmiot a mechanizm, AGD; ser - produkt a nabiat; gang - grupa ludzi a organizacja przestępcza, organizacja oraz ewentualnie szkło - produkt a ciało stałe (chodzi o bardzo szerokie znaczenie wyrazu produkt, obejmujące także efekty procesów naturalnych, przyrodniczych).

Ponadto w przypadku 17 haseł uzyskano od widzących przynajmniej 1 hiperonim o większym stopniu ogólności, niż hiperonimy wspólne dla obu grup ${ }^{14}$ (chodzi tu o hasła, dla których nie uzyskano od niewidomych żadnych hiperonimów innych, niż wspólne z widzącymi). Są to przede wszystkim hasła z klas: Drzewa, Zwierzęta, Budynki, Miejsca handlowo-usługowe, Płyny organizmu, Ludzie, Kosmetyki. Sytuacja odwrotna zachodzi jedynie dla hasła wzgórze. Respondenci widzący częściej, niż niewidomi podają odpowiedzi typu: substancja, istota, organizm, materia, miejsce.

Wyższa ogólność odpowiedzi podawanych tylko przez widzących charakterystyczna jest w takim samym stopniu dla wyrazów silnie, jak i słabo powiązanych z danymi wzrokowymi.

Suma holonimów i quasi-hiperonimów uzyskanych tylko od widzących jest zbliżona do sumy takich reakcji uzyskanych tylko od niewidomych. Jednakże reakcje prawidłowe tego rodzaju stanowią ponad 1/3 wszystkich reakcji inkluzywnych podanych tylko przez niewidomych i około $1 / 5$ wszystkich reakcji inkluzywnych podanych tylko przez widzących. Obie grupy badanych podały po kilka holonimów desygnujących dość duże całości:

- niewidomi: sosna, buk, brzoza, osa - przyroda; wtorek - tysiqclecie; wzgórze - krajobraz oraz bardziej kontrowersyjna reakcja drużyna - tłum (drużyna jako grupa względnie trwała może wejść w skład chwilowego zbiorowiska ludzi, jakie stanowi tłum),

- widzący: sosna, buk-flora; lis - fauna; wtorek - era; gang - społeczeństwo; taka - Ziemia oraz bardziej kontrowersyjna odpowiedź podłoga - Ziemia (por. kryteria analizy semantycznej).

Obie grupy podały znacznie więcej reakcji zakwalifikowanych jako holonimy, niż jako quasihiperonimy. W tej ostatniej grupie reakcji przeważają quasi-hiperonimy oparte na koniecznych częściach lub materiale, np. piwo - chmiel; beton - cement; tęcza - kolor; grad - lód; grad woda; symfonia-dźwięki.

\subsection{Stopień ogólności odpowiedzi prawidłowych rzadkich}

Jako rzadkie określano pozostałe reakcje, tj. reakcje podane przez najwyżej dwie osoby z danej grupy badanych. Na zbiór reakcji rzadkich zakwalifikowanych jako prawidłowe (inkluzywne w stosunku do hasła) składają się zarówno odpowiedzi uznane za hiperonimy haseł, jak i holonimy oraz quasi-hiperonimy. Niektóre rzadkie hiperonimy cechuje szeroki zakres znaczeniowy. Wiele rzadkich holonimów i quasi-hiperonimów można także traktować jako wynik silnej tendencji do uzyskania wysokiego poziomu ogólności.

Wśród odpowiedzi rzadkich pojawiają się rzeczowniki: rzecz (dla 13 haseł zarówno w grupie niewidomych, jak i widzących), przedmiot (dla 12 haseł w grupie niewidomych i dla $7 \mathrm{w}$ grupie widzących) oraz obiekt (dla 5 haseł $\mathrm{w}$ grupie niewidomych i dla $3 \mathrm{w}$ grupie widzących). Odpowiedzi tego typu występują głównie w przypadku haseł z klas: Urządzenia, Budynki, Pożywienie, Miejsca handlowo-usługowe, Pojazdy, Kosmetyki, Dzieła sztuki, Materiały, Części domu. W grupie osób widzących dla 5 haseł podano jako odpowiedź zaimek coś. Wśród odpowiedzi zarówno osób niewidomych, jak i widzących można znaleźć również inne hiperonimy

\footnotetext{
${ }^{12}$ Jako pierwsza podawana jest reakcja niewidomych.

${ }^{13}$ Chodzi o najogólniejsze znaczenie wyrazu przedmiot.

${ }^{14} \mathrm{~W}$ jednym przypadku uwzględniono wymienione wyżej szerokie znaczenie wyrazu produkt.
} 
o wysokiej ogólności: zdarzenie (głównie dla haseł z klas Czynności i Zjawiska atmosferyczne), miejsce i przestrzeń (głównie dla haseł z klas Budynki, Miejsca handlowo-usługowe, Tereny, Elementy pomieszczenia), zjawisko (dla pojedynczych haseł z różnych klas), substancja (głównie dla haseł z klas Płyny organizmu, Kosmetyki i Materiały), istota i organizm (w klasach Drzewa, Owoce i warzywa, Zwierzęta, Ludzie).

Wymienione reakcje pojawiają się także niekiedy wraz $\mathrm{z}$ wyrazami określającymi, zawężającymi ich zakres, np.: (litery $\mathrm{N}$ i W w nawiasach oznaczają pojawianie się reakcji odpowiednio w grupie niewidomych i widzących) mebel - rzecz użyteczna (W); ciężarówka - rzecz ruchoma $(\mathrm{W})$; marchew - rzecz jadalna $(\mathrm{N})$; podtoga - rzecz, po której się chodzi $(\mathrm{N})$; traktor rzecz martwa $(\mathrm{W})$; traktor - przedmiot martwy $(\mathrm{N})$; posag - coś nieruchomego $(\mathrm{W})$; apteka miejsce handlu $(\mathrm{W})$; kawiarnia - miejsce spotkań $(\mathrm{N})$; kamienica - miejsce zamieszkania $(\mathrm{W})$; podtoga - wolna przestrzeń $(\mathrm{W})$; krew - substancja ptynna $(\mathrm{N}$ i W), substancja organiczna $(\mathrm{W})$ itp.

Wiele jest również reakcji rzadkich ujmujących desygnat hasła jako rezultat działania jakiejś istoty/istot lub jako efekt procesów naturalnych, np.: twór, twór natury, twór człowieka, wytwór, wytwór człowieka, wytwór pracy rak ludzkich, wynalazek, wynalazek ludzki, wymyst człowieka, dzieło, dzieło rak ludzkich, dzieło Boga, wyrób, produkt, coś stworzonego przez człowieka itp. (Do tej grupy można by także zaliczyć rekcje typu: stworzenie boże, stworzenie Pana Boga itp.). Odpowiedzi takie pojawiają się dla haseł z kilkunastu klas semantycznych, a najczęściej w klasach: Budynki, Pojazdy, Kosmetyki, Dzieła sztuki, Materiały, Elementy pomieszczenia (reakcje typu stworzenie... występują najczęściej w klasach Zwierzęta oraz Ludzie).

Niektóre reakcje rzadkie można traktować jako efekt stosowania dwóch w jakimś stopniu przeciwstawnych sposobów wyrażania ogólności. Pierwszy z nich polega na odwoływaniu się do budowy desygnatu hasła poprzez połączenie wyrażenia oznaczającego mnogość z określeniem drobnych, niekiedy dość uniwersalnych elementów składowych, np. sosna - zbiór elementów materii $(\mathrm{N})$; jesień - zbiór jednostek czasu $(\mathrm{W})$; oko - zbiór komórek $(\mathrm{W})$; traktor - zbiór części $(\mathrm{W})$; kietbasa - zbiór czqusteczek (W); symfonia - zbiór fal $(\mathrm{N})$; powieść - zbiór informacji (W), zbiór wyrazów (W), zbiór liter (W); krok - zbiór jednostek dtugości $(\mathrm{N})$, także reakcja metajęzykowa typu: uczciwość - układ liter $(\mathrm{N})$ itp. Natomiast odpowiedzi drugiego typu ujmują desygnat hasła jako część jakiejś dużej całości, np. cytryna - element kosmosu $(\mathrm{N})$; wtorek - część ery $(\mathrm{W}) ;$ biedak - czesść społeczeństwa $(\mathrm{W})$, sktadnik świata $(\mathrm{N})$; jaskinia - element środowiska (W); rzeka - sktadnik wszechświata (W).

Oba wymienione sposoby wyrażania ogólności znaleźć można także w reakcjach klasyfikowanych jako holonimy i quasi-hiperonimy haseł. Efektem zredukowania sposobu drugiego do podania nazwy dużej całości jest reakcja holonimiczna, np. sosna - świat $(\mathrm{N})$; cytryna - środowisko $(\mathrm{N})$; wtorek - tysiqclecie $(\mathrm{W})$, milion lat $(\mathrm{N})$, wieczność $(\mathrm{N})$; pałac - królestwo $(\mathrm{W})$; biedak - świat (N); taka - krajobraz (W); komin - wszechświat (W) itp. Natomiast wynik zredukowania odpowiedzi do wyrażenia typu fragment, element itp. kwalifikowano jako quasihiperonim niepełny, np. jesień - fragment $(\mathrm{N})$; metal - element (W); szkto - kawałek (W) itd. Podobnie traktowano nieliczne reakcje ograniczone do wyrażeń oznaczających mnogość, np. księgarnia - skupisko $(\mathrm{W})$; powieść - zbiór $(\mathrm{N})$. Tak samo klasyfikowano odpowiedzi wyrażające łączenie elementów, np. piwo - połqczenie (W); krew - zwiazek (N). Natomiast efekt ograniczania odpowiedzi do podania nazw drobnych, niekiedy uniwersalnych elementów budowy (w liczbie mnogiej) zaliczano do quasi-hiperonimów opartych na częściach koniecznych, np. krew - komórki $(\mathrm{W})$; metal - czastki (W), mimo iż hipotetyczne definicje haseł rozpoczynające się od takich elementów byłyby bardzo nieprecyzyjne.

Wszystkie wymienione sposoby uzyskiwania ogólności są charakterystyczne dla obu badanych grup osób.

Wśród reakcji rzadkich podawanych przez niewidomych znajduje się wiele odpowiedzi identycznych z tymi reakcjami częstymi podanymi przez widzących, które przewyższały swoją ogólnością odpowiedzi częste niewidomych (por. par. poprzedni). (W przypadku 22 z 29 haseł, dla których przynajmniej 1 hiperonim częsty widzących przewyższał ogólnością reakcje częste niewidomych, uzyskano reakcje rzadkie niewidomych identyczne z tymi reakcjami częstymi 
widzących). Ponadto dla wielu haseł występują reakcje hiperonimiczne rzadkie wspólne dla obu grup. Reakcje o wysokim stopniu ogólności: organizm, substancja, miejsce, jako odpowiedzi częste liczniejsze w grupie widzących, jako reakcje rzadkie nieco liczniej pojawiają się w grupie niewidomych.

Liczba haseł, dla których uzyskano większą różnorodność reakcji prawidłowych rzadkich w grupie widzących, niż niewidomych, jest nieznacznie większa od liczby haseł, dla których zachodzi zależność odwrotna (natomiast różnorodność reakcji nieprawidłowych jest dla znacznej większości haseł wyższa w grupie niewidomych).

W grupie niewidomych liczba różnych hiperonimów jest większa, niż liczba różnych holonimów i quasi-hiperonimów, dla 57 haseł, a w grupie widzących - dla 60 haseł. Dla 28 haseł u niewidomych pojawia się wśród reakcji rzadkich więcej różnych holonimów, niż w grupie widzących. Zależność odwrotna zachodzi dla 25 haseł (dla pozostałych haseł liczba różnych holonimów jest taka sama w obu grupach). Dla 41 rzeczowników u niewidomych pojawia się wśród reakcji rzadkich więcej różnych quasi-hiperonimów, niż u widzących. Zależność odwrotna zachodzi jedynie dla 21 rzeczowników. Zatem respondenci niewidomi przejawiają silniejszą niż widzący tendencję do podawania reakcji rzadkich o charakterze quasi-hiperonimów.

\section{Podsumowanie}

Na podstawie wyników opisanego eksperymentu można stwierdzić, że respondenci wykazali dość wysoką umiejętność podawania, jako końcowych elementów ciągów, określeń nadrzędnych w stosunku do haseł. Poziom ogólności takich reakcji jest jednak skorelowany negatywnie z ich siła. Odpowiedzi dominujące, odzwierciedlające typowe sposoby reagowania, cechuje niewielka ogólność. Dotyczy to zwłaszcza odpowiedzi wspólnych dla obu grup, a więc najbardziej powszechnych. Pojawienie się wśród odpowiedzi dominujących kilku rzeczowników bardziej ogólnych może wynikać z braku istnienia sensownych pośrednich poziomów hierarchii między hasłem, takim jak np. tęcza, szkto, uczciwość, a reakcją, taką jak, odpowiednio: zjawisko, substancja, cecha. Wiele reakcji odzwierciedlających słabsze tendencje reagowania, określanych jako częste i rzadkie, przewyższa swoją ogólnością odpowiedzi dominujące. Znaczenie tego stwierdzenia dla oceny umiejętności respondentów w docieraniu do określeń o wysokich poziomach ogólności wzrasta $\mathrm{W}$ powiązaniu $\mathrm{z}$ faktem stosunkowo niewielkiej siły reakcji dominujących.

Badanie pozwoliło na odkrycie dwóch podstawowych sposobów budowania górnych części hierarchii leksykonu:

- poprzez podawanie odpowiedzi nierozczłonkowanych - rzeczowników o szerokich zakresach (jak rzecz, istota, twór, zdarzenie itp.),

- poprzez odniesienie do relacji cześśc - całość wyrażające się w reakcjach - holonimach, stanowiących nazwy całości (np. wszechświat, era) oraz w reakcjach typu: ,zbiór elementów” i „element całości” (np. zbiór komórek, element kosmosu) bądź w odpowiedziach ograniczających się do rzeczowników typu element czy zbiór.

Odwoływanie się w różny sposób do związku część - całość w zadaniu wymagającym (zgodnie $\mathrm{z}$ instrukcją) skoncentrowania się na relacji zawierania się klas może dowodzić dużej roli hierarchii opartych na relacjach część - całość w leksykonie umysłowym, spowodowanej być może silniejszym powiązaniem tej relacji z fizyczną rzeczywistością (por. Cruse 1986).

Zarówno poziom umiejętności podawania określeń nadrzędnych w stosunku do hasła jako elementów końcowych ciągu, jak i poziom ogólności odpowiedzi poprawnych są nieco niższe w grupie respondentów niewidomych. Różnica w poprawności odpowiedzi nie dotyczy jednak reakcji dominujących, ujawnia się dopiero w tendencjach słabszych, a więc w tzw. reakcjach częstych i rzadkich. Niższy stopień poprawności wyników osób niewidomych przejawia się zarówno w mniej korzystnym stosunku reakcji częstych inkluzywnych do nieinkluzywnych i w większej różnorodności reakcji nieprawidłowych rzadkich, jak i w większym udziale reakcji prawidłowych nie stanowiących hiperonimów, a więc reakcji holonimicznych i quasi-hiperonimicznych. 
Natomiast różnice w ogólności reakcji między grupami badanych osób widoczne są już na poziomie reakcji dominujących, a najsilniej przejawiają się w reakcjach częstych. Różnice te wyrównują się na poziomie reakcji rzadkich: pojedyncze ogólne reakcje niewidomych często stanowią dokładne odpowiedniki reakcji częstych podanych przez widzących, w związku z czym niektóre wyrazy o szerokich zakresach występują w takich pojedynczych reakcjach częściej w grupie niewidomych. Zatem tendencja do podawania określeń ogólnych jako elementów końcowych ciągów definicyjnych jest silniejsza w grupie respondentów widzących, chociaż sposoby określania górnych poziomów hierarchii są podobne w obu grupach badanych osób.

Nieco słabsze rezultaty niewidomych w opisywanym badaniu można interpretować jako wynik ogólnie mniejszego zasobu doświadczeń dotyczących różnych aspektów rzeczywistości. Słuszność takiej tezy może w jakimś stopniu potwierdzać pewna (niewielka) zależność łatwości podawania reakcji prawidłowych przez niewidomych od stopnia wizualności hasła.

Przeprowadzone badanie psycholingwistyczne wykazało potencjalną możliwość docierania przez użytkowników języka do wyrażeń o bardzo szerokich zakresach znaczeniowych poprzez odtwarzanie hierarchicznej struktury leksykonu umysłowego. Stopień tej umiejętności jest prawdopodobnie uzależniony od bardzo wielu czynników. Jednym z nich może być sprawność narządów zmysłów, dostarczających informacji o desygnatach wyrażeń językowych.

\section{Literatura cytowana}

Allan, K. 2001. Natural language semantics. Oxford: Blackwell Publishers.

Apresjan, J. 1972. Definiowanie znaczeń leksykalnych jako zagadnienie semantyki teoretycznej. [W:] A. Wierzbicka (red.) Semantyka i stownik. Wrocław: Ossolineum. ss. 39-57.

Artowicz, E. 1990. O budowie tzw. ciągów definicyjnych na materiale definicji leksykalnych polskich i węgierskich. Acta Philologica 21. ss. 51-72.

Bańczerowski, J., Pogonowski, J., Zgółka, T. 1982. Wstęp do językoznawstwa. Poznań: UAM.

Bloom, P. 2000. How children learn the meanings of words. London, Cambridge: MIT Press.

Collins, A. M. \& Quillian, M.R. 1969. Retrieval time from semantic memory. Journal of Verbal Learning and Verbal Behavior 8. ss. 240-248.

Cruse, D.A. 1986. Lexical semantics. Cambridge: Cambridge University Press.

Cruse, D. A. 2000. Meaning in language. An introduction to semantics and pragmatics. Oxford: University

Deese, J. 1965. The structure of associations in language and thought. Baltimore: John Hopkins Press.

Dolan, W., Vardenwende, L., Richardson, S. 2002. Polysemy in a broad-coverage natural language. [W:] Y. Ravin, C. Leacock (Red.). Polysemy. Oxford: University Press. ss. 178-204.

Fellbaum, Ch. 1993. English verbs as a semantic net. Princeton.

Forster, K.I. 1976. Accessing the mental lexicon. [W:] F.J. Wales, E. Walker (red.). New approaches to language mechanisms. Amsterdam: North-Holland. ss. 257-287.

Grochowski, M. 1985. Theoretical problems of truthfulness justification of lexical units semantic definitions (for L1 lexicography). [W:] J. Tomaszczyk, B. Lewandowska-Tomaszczyk (red.). International conference on meaning and lexicography. Łódź: Uniwersytet Łódzki. ss. 20-21.

Grodziński, E. 1985. Językoznawcy i logicy o synonimach i synonimii. Wrocław: Ossolineum.

Grzegorczykowa, R. 1988. Problem derywatów i wyrazów polisemicznych w opisie słownikowym. [W:] W. Lubaś (Red.). Wokót stownika wspótczesnego języka polskiego. Wrocław: Ossolineum. ss. 63-77.

Habrajska, G. 1996. Kategoryzacja a klasyfikacja - potoczne i naukowe widzenie świata (analiza badań ankietowych dotyczących kategoryzacji nazw roślin). [W:] R. Grzegorczykowa, A. Pajdzińska (red.). Językowa kategoryzacja świata. Lublin: UMCS. ss. 221-233.

Hammerl, R., Sambor, J. 1993. O statystycznych prawach językowych. Warszawa: Polskie Towarzystwo Semiotyczne.

Kleiber, G., Tamba, I. 1990. L’hyponymie revisitée: inclusions et hiérarchie. Langages 98. ss. 7-32.

Kurcz, I. 1967. Polskie normy powszechności skojarzeń swobodnych na 100 słów z listy Kent-Rosanoffa. Studia Psychologiczne t. VIII. ss. 122-255.

Levelt, W.J.M., Roelofs, A., Meyer, A.S. 2002. A theory of lexical access in speech production, [W:] G.T.M. Altmann (red.). Psycholinguistics. Critical concepts in psychology. T. V. London and New York: Routledge. ss. 278-377.

Lyons, J. 1984. Semantyka. Warszawa: PWN.

Łobacz, P., Mikołajczak-Matyja, N. 2002. Skojarzenia stowne $w$ psycholeksykologii $i$ onomastyce psycholingwistycznej. Poznań: Sorus. 
Martin, R. 1974. Syntaxe de la définition lexicographique: étude quantitative des définissants dans le „Dictionnaire fondamental de la langue française”. [W:] J. David, R. Martin (red.). Statistique et linguistique. Paris. ss. 61-71.

McClelland, J. \& Rumelhart, D. 1981. An interactive activation model of context effects in letter perception. Part 1: An account of basic findings. Psychological Review 88. ss. 60-94.

McGhee-Bidlack, B. 1991. The development of noun definitions: a metalinguistic analysis. Journal of Child Language 18. ss. 417-434.

Mikołajczak-Matyja, N. 1998. Definiowanie pojęć przez przeciętnych użytkowników języka $i$ przez leksykografów. Poznań: Sorus.

Mikołajczak-Matyja, N. 1999. Reguły definiowania a praktyka leksykograficzna. Studia z Filologii Polskiej $i$ Stowiańskiej 35. Warszawa: SOW. ss. 67-107.

Miller, G.A. 1993. Nouns in WordNet: a lexical inheritance system. Princeton.

Miller, G.A., Beckwith, R., Fellbaum, Ch., Gross, D., Miller, K. 1993. Introduction to WordNet: an on-line lexical database, Princeton.

Péchoin, D. 1989. Table ronde. [W:] A.H. Ibrahim, M. Zalessky (red). Français dans le monde No spécial. ss. 60-66.

Quemada, B. 1968. Les dictionnaires du français moderne. Paris: Didier.

Reeves, L.M., Hirsh-Pasek, K., Golinkoff, R. 1998. Words and meaning: from primitives to complex organization. [W:] J.B. Gleason, N.B. Ratner (red.). Psycholinguistics. Orlando: Harcourt Brace College Publishers. ss. 157-226.

Rey-Debove, J. 1971. Étude linguistique et sémiotique des dictionnaires français contemporains. Paris: Mouton.

Saeed, J.I. 1998. Semantics. Oxford: Blackwell Publishers.

Sambor, J., Zagrodzka, T. 1993. Struktura hierarchiczna hiperonimów w eksperymencie psycholingwistycznym (na materiale nazw roślin). [W:] J. Bartmiński, R. Tokarski (red.). $O$ definicjach $i$ definiowaniu. Lublin: UMCS. ss. 305-319.

[SJPDor]: Doroszewski, W. (red.). 1958 - 1969. Stownik języka polskiego. Warszawa: PWN. T. I - XI.

[SJPDun]: Dunaj, B. (Red.). 1996. Słownik współczesnego języka polskiego, Warszawa: Wilga..

[SJPSz]: Szymczak, M. (red.).1983. Stownik języka polskiego. Warszawa: PWN. T. I - III.

[SJPZg]: Zgółkowa, H. (red.). 1995 - 2003. Praktyczny słownik współczesnej polszczyzny. Poznań: Kurpisz. T. I-XL.

Szczekocka-Augustyn, A., Wereszczyńska, B., Zagrodzka, T. 1996. O kategoriach rozmytych (na przykładzie rozumienia nazw fauny, flory i artefaktów). [W:] R. Grzegorczykowa, A. Pajdzińska (red.). Językowa kategoryzacja świata. Lublin: UMCS. ss. 255-272.

Tokarski, R. 1987. Znaczenie słowa i jego modyfikacje w tekście. Lublin: UMCS.

Woodworth, R.S., Schlosberg, H. 1963. Psychologia eksperymentalna. Warszawa: PWN.

\section{Summary}

Hierarchising constitutes an important aspect of the structure of natural language and an important principle of organisation of the mental lexicon. One of the main problems concerning the possibility of hierarchically ordering large sets of lexis consists in finding an element comprising the highest (the most generic) level of the hierarchy.

The main objective of the present paper consisted in discovering methods of reconstructing the upper levels of the hierarchy of the mental dictionary by naïve (average) language users and establishing whether the mechanisms of such reconstruction depend on the possibility of obtaining extra-linguistic data, or - to be more precise - visual data. 58 sighted persons and 58 blind persons (completely blind or only with a minimal light perception) were instructed to create hierarchical series (chains) of hypernyms (series of words, in which the following is invariably the hypernym of the former) for 75 Polish nouns belonging to various lexical fields. The analysis centred on the final elements of these series. It was established that respondents carried out the task on the whole correctly: on average, approximately $70 \%$ of the group stated, as the final elements of the series, inclusive reactions, such as hypernyms, holonyms (superordinated elements of the part - whole relation, i.e. meronymy) and quasi-hypernyms of entries. The level of generality of hypernyms is negatively connected with their strength (the more general the hypernym, the less its commonness). 
It was also established that the participants attempted to construct levels with a high degree of generality by:

1. searching for nouns with very broad meanings, such as: rzecz, istota, zdarzenie, twór (thing, being, event, creature/origination/production),

2. referring to the part - whole relation, that is:

- searching for holonyms designating very large "wholes", such as universe, era, etc.,

- constructing compound expressions, such as "a set of elements" and "an element of the whole", e.g. a set of cells, an element of the universe,

- minimising such expressions to single words: set, element etc.

Replacement of the search for hypernyms with references to the part - whole relation may be interpreted as evidence of the important role of the part - whole hierarchy in the organisation of the mental lexicon. The significance of relations of this type may result from the fact that meronomies (part - whole hierarchies) are more intimately tied to concrete physical reality than hierarchies based on a hyponymy.

Blind participants performed the experimental task worse than those with unimpaired eyesight did. They provided less hypernyms and more holonyms, quasi-hypernyms and non-inclusive reactions than the other group of participants. Furthermore, the common (i.e. recurring) responses of the experimental group of the blind were characterised by a lower degree of generality than the common responses of the control group. However, the methods of constructing levels with a high degree of generality were the same for both groups of participants. The inferior results of the blind could have been caused by the relatively greater ease of obtaining information concerning various aspects of reality by sighted persons than by the blind. This supposition was partially confirmed by the finding that the ability of searching for levels with a high degree of generality by the blind depends (to a certain extent) on the visual character of the entry (i.e. on the share of visual information in determining the meaning of an entry by sighted persons).

The present paper has shown that average language users may uncover expressions with very broad meanings. The development of this skill is probably dependent on a number of factors. Properly functioning sense organs, which provide the subject with information about reality, may constitute one of these factors. 